\title{
Essential coastal habitats for fish in the Baltic Sea
}

\section{Kraufvelin, Patrik}

2018-05-01

Kraufvelin , P , Pekcan-Hekim , Z , Bergström , U , Florin , A-B , Lehikoinen , A , Mattila , J , Arula, T, Briekmane , L, Brown, E J, Celmer, Z, Dainys , J, Jokinen, H, Kääriä , P , Kallasvuo , M , Lappalainen, A , Lozys , L , Möller , P , Orio , A , Rohtla , M , Saks , L , Snickars , M , Støttrup , J Sundblad, G , Taal , I , Ustups , D , Verliin , A, Vetemaa , M , Winkler , H , Wozniczka , A \& Olsson , J 2018 , ' Essential coastal habitats for fish in the Baltic Sea ' , Estuarine, Coastal and Shelf Science , vol. 204 , pp. 14-30 . https://doi.org/10.1016/j.ecss.2018.02.014

cc_by_nc_nd

acceptedVersion

Downloaded from Helda, University of Helsinki institutional repository.

This is an electronic reprint of the original article.

This reprint may differ from the original in pagination and typographic detail.

Please cite the original version. 


\section{Accepted Manuscript}

Essential coastal habitats for fish in the Baltic Sea

Patrik Kraufvelin, Zeynep Pekcan-Hekim, Ulf Bergström, Ann-Britt Florin, Annukka Lehikoinen, Johanna Mattila, Timo Arula, Laura Briekmane, Elliot John Brown, Zuzanna Celmer, Justas Dainys, Henri Jokinen, Petra Kääriä, Meri Kallasvuo, Antti Lappalainen, Linas Lozys, Peter Möller, Alessandro Orio, Mehis Rohtla, Lauri Saks, Martin Snickars, Josianne Støttrup, Göran Sundblad, Imre Taal, Didzis Ustups, Aare Verliin, Markus Vetemaa, Helmut Winkler, Adam Wozniczka, Jens Olsson

PII: S0272-7714(17)30622-4

DOI: 10.1016/j.ecss.2018.02.014

Reference: YECSS 5755

To appear in: Estuarine, Coastal and Shelf Science

Received Date: 11 June 2017

Revised Date: 1 December 2017

Accepted Date: 12 February 2018

Please cite this article as: Kraufvelin, P., Pekcan-Hekim, Z., Bergström, U., Florin, A.-B., Lehikoinen, A., Mattila, J., Arula, T., Briekmane, L., Brown, E.J., Celmer, Z., Dainys, J., Jokinen, H., Kääriä, P., Kallasvuo, M., Lappalainen, A., Lozys, L., Möller, P., Orio, A., Rohtla, M., Saks, L., Snickars, M., Støttrup, J., Sundblad, Gö., Taal, I., Ustups, D., Verliin, A., Vetemaa, M., Winkler, H., Wozniczka, A., Olsson, J., Essential coastal habitats for fish in the Baltic Sea, Estuarine, Coastal and Shelf Science (2018), doi: 10.1016/j.ecss.2018.02.014.

This is a PDF file of an unedited manuscript that has been accepted for publication. As a service to our customers we are providing this early version of the manuscript. The manuscript will undergo copyediting, typesetting, and review of the resulting proof before it is published in its final form. Please note that during the production process errors may be discovered which could affect the content, and all legal disclaimers that apply to the journal pertain. 


\section{Essential coastal habitats for fish in the Baltic Sea}

2 Patrik Kraufvelin(a,b,* Zeynep Pekcan-Hekim(a, Ulf Bergström(a, Ann-Britt Florin(a,

3 Annukka Lehikoinen(a,c, Johanna Mattila(a,b, Timo Arula(d, Laura Briekmane(e,

4 Elliot John Brown(f, Zuzanna Celmer(g, Justas Dainys ${ }^{(h}$, Henri Jokinen(i, Petra

5 Kääriä(j, Meri Kallasvuo(k, Antti Lappalainen(k, Linas Lozys ${ }^{(h)}, P^{(2 t e r}$ Möller $^{(1}$, 6 Alessandro $\operatorname{Orio}^{(m}$, Mehis Rohtla(d, Lauri Saks(d, Martin Snickars(b, Josianne 7 Støttrup(f, Göran Sundblad(n,o, Imre Taal(d, Didzis Ustups(e, Aare Verliin(d, Markus 8 Vetemaa $^{(d,}$, Helmut Winkler(p, Adam Wozniczka(g \& Jens Olsson ${ }^{a}$ 9

10 a. Swedish University of Agricultural Sciences, Department of Aquatic Resources, 11 Institute of Coastal Research, Skolgatan 6, 74242 Öregrund, Sweden

12 b. Åbo Akademi University, Environmental and Marine Biology, Turku, Finland

13 c. University of Helsinki, Kotka Maritime Research Centre, Kotka, Finland

14 d. Estonian Marine Institute, University of Tartu, Tartu, Estonia

15 e. Institute of Food Safety, Animal Health and Environment "BIOR", Riga, Latvia

16 f. DTU Aqua, National Institute of Aquatic Resources, Technical University of Denmark,

17 Lyngby, Denmark

18 g. National Marine Fisheries Research Institute, Gdynia, Poland

19 h. Nature Research Centre, Vilnius, Lithuania

20 i. University of Helsinki, Tvärminne Zoological Station, Hanko, Finland 
21 j. HELCOM Secretariat, Helsinki, Finland

22 k. Natural Resources Institute Finland (Luke), Helsinki, Finland

23 l. Fisch und Umwelt, Mecklenburg-Vorpommern, Rostock, Germany

24 m. Swedish University of Agricultural Sciences, Department of Aquatic Resources, 25 Institute of Marine Research, Lysekil, Sweden

26 n. AquaBiota Water Research, Stockholm, Sweden

o. Swedish University of Agricultural Sciences, Department of Aquatic Resources, Institute of Freshwater Research, Drottningholm, Sweden

* corresponding author: patrik.kraufvelin@slu.se; patrik.kraufvelin@abo.fi

\section{ABSTRACT}

Many coastal and offshore fish species are highly dependent on specific habitat types for population maintenance. In the Baltic Sea, shallow productive habitats in the coastal zone such as wetlands, vegetated flads/lagoons and sheltered bays as well as more exposed rocky and sandy areas are utilised by fish across many life history stages including spawning, juvenile development, feeding and migration. Although there is general consensus about the critical importance of these essential fish habitats (EFH) for fish production along the coast, direct quantitative evidence for their specific roles in

41 population growth and maintenance is still scarce. Nevertheless, for some coastal 
species, indirect evidence exists, and in many cases, sufficient data are also available to carry out further quantitative analyses. As coastal EFH in the Baltic Sea are often found in areas that are highly utilized and valued by humans, they are subjected to many different pressures. While cumulative pressures, such as eutrophication, coastal construction and development, climate change, invasive species and fisheries, impact fish in coastal areas, the conservation coverage for EFH in these areas remains poor. This is mainly due to the fact that historically, fisheries management and nature conservation are not integrated neither in research nor in management in Baltic Sea countries. Setting joint objectives for fisheries management and nature conservation would hence be pivotal for improved protection of EFH in the Baltic Sea. To properly inform management, improvements in the development of monitoring strategies and mapping methodology for EFH are also needed. Stronger international cooperation between Baltic Sea states will facilitate improved management outcomes across ecologically arbitrary boundaries. This is especially important for successful implementation of international agreements and legislative directives such as the Baltic Sea Action Plan, the Marine Strategy Framework Directive, the Habitats Directive, and the Maritime Spatial Planning Directive, but also for improving the communication of information related to coastal EFH among researchers, stakeholders, managers and decision makers. In this paper, efforts are made to characterize coastal EFH in the Baltic Sea, their importance and the threats/pressures they face, as well as their current conservation status, while highlighting knowledge gaps and outlining perspectives for future work in an ecosystem-based management framework. 


\section{INTRODUCTION AND BACKGROUND}

68

Fish are central for the functioning of food webs and ecosystems in the Baltic Sea (Österblom et al. 2007, Östman et al. 2016), and are broadly used in environmental monitoring as indicators for ecosystem status and health (Bergström et al. 2016ab). Fish are also important in socio-economic terms, such as for commercial and recreational fisheries (Holmlund and Hammer 1999). The geographical distribution and occurrence of fish in the Baltic Sea, and thereby the species composition of fish communities, differ over both large and small scales. Fish distributions are largely driven by spatiotemporal differences in natural biotic and abiotic factors as well as by human pressures (Bergström et al. 2016a, Östman et al. 2017). The same habitat may have only one or several functions during different seasons with regard to e.g. spawning, feeding and overwintering for the same or different species (Aro 1989, Vetemaa et al. 2006). Examples of common gradients and factors that are determining fish distribution are salinity, temperature, depth, pollution, eutrophication, predation, food availability, fishing pressure, and also the availability and conditions of coastal essential fish habitats (EFH) which is the focus of this review article (Leppäkoski and Bonsdorff 1989, Sparholt 1994, Bonsdorff and Pearson 1999, MacKenzie et al. 2007, HELCOM 2010, Olsson et al. 2012, Seitz et al. 2014). In the review, efforts are made to characterize coastal EFH in the Baltic Sea, their importance and the threats/pressures they face, as well as their current conservation status, while highlighting knowledge gaps and outlining perspectives for future work in an ecosystem-based management framework.

In a broad sense, an EFH is any environment that is needed for the maintenance of a fish population. More specifically, coastal EFH are defined as shallow and nearshore 
waters and substrates necessary to any life-stage of fish for spawning, breeding, feeding or growth to maturity (Benaka et al. 1999, Rosenberg et al. 2000). In this respect, the term waters include all aquatic coastal areas (down to a maximum depth of 10-20 m) and their physical, chemical, and biological properties, whereas substrates include surfaces and their associated biological communities that make them suitable as fish habitats (Rosenberg et al. 2000). Coastal EFH are thus comprised of juvenile growth areas, foraging areas, reproduction areas and migratory routes. While the latter three are of direct importance for fisheries, by offering high catches or value per fishing effort (Airoldi and Beck 2007, Seitz et al. 2014), the former one is a step required to produce recruits to replenish the fishery (Beck et al. 2001). Fishing may, however, be challenging for the sustainable management of some coastal EFH, not only as some fishing practices are detrimental to the habitats per se, but also because targeted extraction of species from the general marine ecosystem may indirectly influence the habitats by altering predator-prey interactions (Hopkins 2003, Eriksson et al. 2011, Pikitch et al. 2014, Östman et al. 2016, Pommer et al. 2016, Eddy et al. 2017). Despite consensus among scientists on the critical importance of EFH, their role for sustaining fish stocks and communities has received relatively little attention (Beck et al. 2001, Gillanders et al. 2003, Armstrong and Falk-Petersen 2008, Sheaves et al. 2015). The influence of the amount and quality of EFH on fish population dynamics has generally been poorly described in the scientific literature, and only rarely, has the information been incorporated into scientific advice for fisheries management (Mangel et al. 2006, Armstrong and Falk-Petersen 2008, Thrush and Dayton 2010, Kallasvuo et al. 2017). As coastal EFH are often found in areas that are highly valued and utilized by humans (de Groot et al. 2012, Šiaulys et al. 2012), numerous pressures/threats and management 
116

issues are implied (Korpinen et al. 2012) and thus the gaps in knowledge with regard to the importance of coastal EFH need to be addressed (Sundblad and Bergström 2014).

\section{Coastal EFH represent "home grounds" for coastal fish species throughout their lives} and for other fish species during different life history stages when they are using the coastal zone. Major coastal EFH consist of: (1) coastal wetlands and shallow bays (including salt marshes, estuaries, river mouths, coastal lagoons and flads), (2) shallow vegetated areas (including seagrass meadows and macroalgal beds, but also freshwater plants in brackish water areas), (3) biogenic reefs and hard structures (including mussel beds, rocky shores, mariculture installations and other artificial substrates) and (4) unvegetated soft and sandy areas and shallow open water (modified from Seitz et al. 2014). Thus, basically, most types of shallow benthic and pelagic areas can function as coastal EFH, at least for some species at some life stage. In temperate waters, shallow and wave-sheltered EFH are generally characterised by higher water temperatures, extensive macrophyte vegetation and a particularly high production of zooplankton and zoobenthic prey, thus providing excellent conditions for survival and growth of fish larvae and juveniles (Blaber and Blaber 1980, Karås and Hudd 1993, Gibson 1994, Karås 1996, Ljunggren 2002, Stål et al. 2007, Härmä et al. 2008, Kallasvuo et al. 2009, Snickars et al. 2009, 2010, Ljunggren et al. 2010, Seitz et al. 2014). Many habitats, such as seagrass and macrophyte meadows, perennial macroalgal belts and mussel beds, also aid in maintaining fish populations by providing three-dimensional benthic structures serving as more or less permanent habitats, temporary nursery areas, rich feeding areas and refuges/shelter from predation (Rajasilta et al. 1989, Jackson E.L. et al. 2001, Pihl and Wennhage 2002, Lappalainen et al. 2004, 2005, 2008, Härmä et al. 2008, Díaz et al. 2015). Mariculture installations, artificial substrates and rocky bottoms, in turn, are 
141 important for providing surfaces for habitat-forming macroalgae and sessile animals,

142 which serve as food and refuge from predation (Pihl and Wennhage 2002, Seaman 2007,

143 Fabi et al. 2011, Kraufvelin and Díaz 2015, Bergström et al. 2016c). Finally, seabeds

144 without macroscopic vegetation as well as open shallow waters are often highly

145 productive, both with regard to primary and secondary production (Gerbersdorf et al.

146 2005, Engelsen et al. 2008). As such they support a diverse range of fish by providing

147 spawning, juvenile growth, feeding and resting grounds (McCormick et al. 1998,

148 Wennhage and Pihl 2002, Cattrijsse and Hampel 2006, Florin et al. 2009, Seitz et al. 149 2014).

Despite the increased attention during recent years towards characterizing EFH in

152 the Baltic Sea (HELCOM 2012, Sundblad et al. 2014, Kallasvuo et al. 2017), sufficient

153 information is lacking for many fish species to quantitatively assess the role of coastal

154 habitats for fish population growth and production. In this review, the main focus is on

155 the role of coastal essential habitats for commercial, threatened and ecologically

156 important (from a conservation perspective) fish species. The species and groups that

157 benefit from a decrease in the environmental status of the Baltic Sea, such as cyprinids

158 (Bergström et al. 2016ab) and three-spined stickleback (Gasterosteus aculeatus)

159 (Bergström et al. 2015, Byström et al. 2015), are thus excluded. Within this process, the

160 threats to and current conservation status of coastal EFH in the Baltic Sea are also

161 thoroughly reviewed, while knowledge gaps are highlighted and perspectives for future

162 work on this topic within an ecosystem-based management framework are outlined. 


\section{OCCURRENCE AND IMPORTANCE OF COASTAL EFH IN THE BALTIC SEA}

168

\subsection{Occurrence of coastal EFH in the Baltic Sea}

The Baltic Sea is the world's largest semi-enclosed brackish water area, with a surface salinity gradient ranging from 2 in the northern and easternmost parts to 31 in Kattegat in the southwest. It is relatively shallow in relation to its size, with the coastal zone constituting a large and important part of the ecosystem. Figure 1, from HELCOM (2010), illustrates the richness of habitat types (named ecosystem components) in different parts of the Baltic Sea. The categorization of the ecosystem components in this figure closely resembles the EFH categorization used in this review, apart from a few classes based on species data and deeper aphotic bottoms away from the coast, and can thus, in our opinion, be used as a proxy for EFH in the Baltic Sea.

\section{In the context of Figure 1, an ecosystem component refers to biological parts of the} ecosystem such as species, biotopes formed by habitat-forming species or abiotic biotopes with a clear linkage to certain species (Korpinen et al. 2012). The 14 named ecosystem components in Korpinen et al. (2012) are divided into benthic biotopes (two), benthic biotope complexes (six), water column (two) and species data (four). In the map the habitats specifically constitute: 1) mussel beds and 2) eelgrass meadows (benthic biotopes); 3) photic sand, 4) non-photic sand, 5) photic mud and clay, 6) nonphotic mud and clay, 7) photic hard bottom and 8) non-photic hard bottom (benthic biotope complexes); 9) photic water and 10) non-photic water (water column); as well as 11) harbour porpoise, 12) seals, 13) seabird wintering grounds and 14) spawning and nursery areas of cod (species data). Note, however, that for the purposes of this review, a number of ecosystem components from the list above are not fully 
191

192

193

194

195

196

197

synonymous to coastal EFH, as the term is interpreted and used in the present study.

This clearly applies to the species data points 11-13 above, but also partly to non-photic bottoms (points 4, 6 and 8 above) and non-photic water column (point 10), i.e. for those parts that are occurring deeper down and farther away from the shoreline.

5

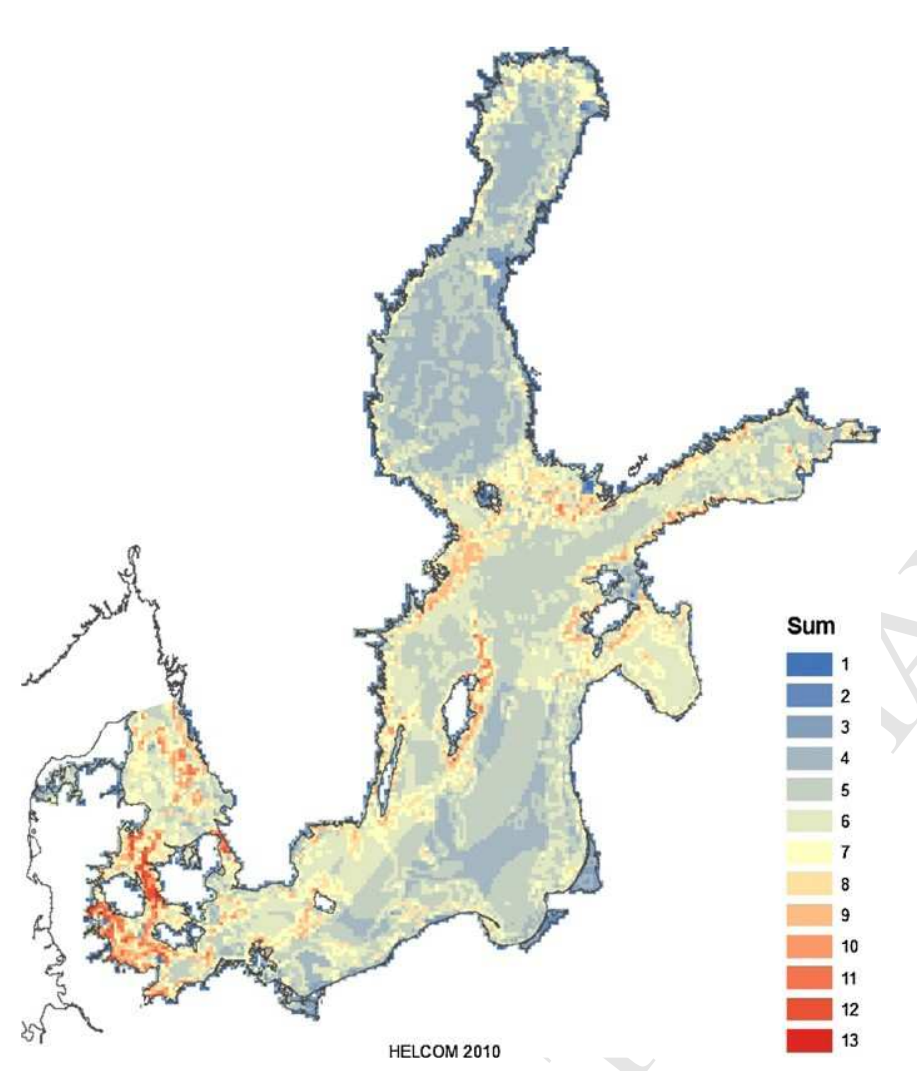

Figure 1. Map showing the number of ecosystem components present (benthic and water column biotope complexes, benthic biotopes and species-related data layers) as a proxy for EFH in $5 \mathrm{~km} \times 5 \mathrm{~km}$ squares in the Baltic Sea. Altogether 14 data layers were used when constructing the map, but no single square contained all ecosystem components. The map is taken from HELCOM (2010), with permission.

If the ecosystem components from Korpinen et al. (2012) and coastal EFH in the Baltic Sea are considered to be of the same kind, the richest diversity of components/EFH is found in squares in the southwestern Baltic Sea, for example in the Sound, in the Belts and in Kattegat. A reasonably high diversity of components/EFH are also found around the large islands and in the archipelagos of the central Baltic Proper. 
10

Lower diversities (fewer EFH) are found in the Bothnian Bay and in the eastern parts of

211 the Baltic Sea (Figure 1).

\subsection{Importance of coastal EFH in the Baltic Sea}

The importance of coastal EFH can in general be assessed as the effects of changes in

their quantity or quality on metrics of viability and production of fish populations, stocks or communities in time or space (e.g. Levin and Stunz 2005, Sundblad et al. 2014). A recent review by Seitz et al. (2014) shows that in the Northeast Atlantic, $44 \%$ of

all "ICES species", i.e. species assessed and advised by the International Council for the

Exploration of the Sea, utilizes coastal habitats as spawning, feeding, nursery or

migration areas. These stocks contribute to $77 \%$ of the commercial landings of the "ICES

species". It follows then, that a limited habitat supply, possibly acting independently at

different life-history stages utilising different habitats, can impact the size and dynamics

of fish populations, although the relationships are not easily quantified (Seitz et al. 2014,

Vasconcelos et al. 2014, Kallasvuo et al. 2017).

The available quantitative evidence for the importance of coastal habitats for fish production and viability has been achieved through a number of different approaches.

These approaches include e.g. model based ones (e.g. Minns et al. 1996, Halpern et al. 2005, Levin and Stunz 2005, Fodrie et al. 2009), long-term field experiments (Schmitt and Holbrook 2000), otolith chemistry (e.g. Fodrie and Levin 2008), habitat specific

231 (Rijnsdorp et al. 1992). Species distribution modelling has, in this respect, emerged as a 232 promising tool to map specific habitat requirements for different life stages of species 233 with ontogenetic habitat shifts (Bergström et al. 2013, Sundblad et al. 2014). By using 234 modelling techniques, species occurrence or abundance can be related to map-based 
predictor variables and thereby, fine-scale mapping of the distribution of species and habitats across spatially heterogeneous ecosystems can be carried out (Elith and Leathwick 2009, Pittman and Brown 2011, Bučas et al. 2013, Kotta et al. 2016, Moore et al. 2016).

\subsubsection{Direct and indirect evidence of the effects of coastal EFH on fish population} size

From the Baltic Sea, some case studies give direct (quantitative) evidence on the role of coastal EFH for fish populations and fish production, although most of the evidence can be characterised as indirect (Table 1). Also, there do not seem to be any studies available from the Baltic Sea utilizing habitat-specific demographic rates, although this has been a preferred method for demonstrating habitat dependence in many circumstances globally (Levin and Stunz 2005, Vasconcelos et al. 2014). As may be noticed from the case studies below, the area of establishing direct links between

250 habitats and fish populations is quite understudied in the Baltic Sea and most evidence seems to be available between habitats and larval fish, not directly for adult populations.

Despite the fairly low number of studies showing direct links between fish stock sizes and availability of habitats, a reasonable amount of data on occurrence, or preferentially abundance, of various life stages of different fish species in specific habitats still indirectly indicate the importance of coastal EFH and help in their further identification 256 and verification.

As direct evidence, Sundblad et al. (2014) used species distribution modelling on data from Sweden and Finland and related the distribution of nursery habitats for perch, 
Perca fluviatilis, and pikeperch, Sander lucioperca, to the size of the adult populations of these species in twelve archipelago areas in the northern Baltic Proper. By doing this, the authors reveal that availability of coastal EFH explains almost half of the variation in population size, indicating a crucial role in limiting adult stock sizes. The relationships are, however, non-linear, suggesting that the negative effects of e.g. habitat loss or positive effects of e.g. restoration measures will be most significant in areas with the most limited habitat availability.

For whitefish, Coregonus lavaretus, Vanhatalo et al. (2012) utilized data from both the Swedish and Finnish coasts of the Gulf of Bothnia to establish direct relationships between environmental variables characterizing coastal EFH and larval production. Vanhatalo and colleagues used Gaussian processes for species distribution modelling and show that the most important variables describing potential larval areas over large scales, are bottom type, prolonged ice period in spring, ecological status of coastal areas, distance to large shallow sand areas and water depth. Thus, the most important variables are descriptors of coastal EFH for whitefish larvae and a metric of the current level of human impact on these areas.

In a recent Finnish case study, as a final example of direct connections between coastal EFH and coastal fish populations in the Baltic Sea, Kallasvuo et al. (2017) assessed the most important reproduction habitats for fish by using larval survey data and Bayesian species distribution models. By utilising data for four commercially and ecologically important fish species along the Finnish coast, Baltic herring (Clupea harengus membras), perch, pikeperch and smelt (Osmerus eperlanus), Kallasvuo and colleagues demonstrate that the production of fish stocks can be concentrated to very 
285 limited areas compared to the total suitable production area that is available. Thus, 286 spawning areas that are highly effective relative to the general pool of spawning areas 287 can be identified. The applied methodology enables linking of the total production 288 potential across the whole distribution area to fisheries stock assessment and 289 management, especially for more strictly coastal species such as perch and pikeperch.

that show the direct relationship between the volume of EFH for reproduction and the adult stock. MacKenzie et al. (2000) estimated reproduction volumes in time and space and demonstrate that the volume of EFH for egg survival determines the interannual stability in hatching success of cod eggs, while Cardinale and Arrhenius (2000) by the use of generalized additive models show that the volume of EFH for reproduction also affects cod recruitment. These results for cod are, however, not primarily focusing on coastal EFH. Still, with regard to coastal EFH, a recent study by Hinrichsen et al. (2017)

299 demonstrates the importance of habitat availability for juvenile cod (nursery) and its 300 effect on density-dependent growth, as a process relevant for recruitment success. Thus, across multiple life history stages, EFH availability influences stock size.

The remaining case studies presented in this chapter and in Table 1 are more 304 indirect with regard to the connections between coastal EFH and fish populations, although there are no sharp distinctions between the direct studies mentioned above and the indirect ones mentioned below. 
in relation to anthropogenic stressors shows good compliance with fish reproduction data. Bays that are dominated by stress sensitive macrophyte species also prove to be

312 important nursery areas for fish. In another case study from Sweden and Finland, 313 Snickars et al. (2010) report that distribution of spawning habitat for perch depends

314 strongly on the type of substrate. The substrates generally consist of different types of 315 vegetation, where the ones providing rigidity and structural complexity are preferred by 316 the perch. Also, water depth, wave exposure and temperature matter to a relatively high 317 extent with shallow depths and sheltered areas being preferred habitat characteristics. 318 No direct links to the size of perch stocks have, however, been established.

In another case study from southern Finland, Engström-Öst et al. (2007) compared habitat choice and survival of pike larvae (Esox lucius) experimentally and conclude that pike larvae prefer and also survive better in filamentous algae (Cladophora glomerata) than in bladderwrack (Fucus vesiculosus) in the presence of predators. This is probably because the bladderwrack habitat is too "open" for the newly hatched pikes. In a related experimental study, Engström-Öst and Mattila (2008) compared the performance of larval pike under the influence of turbidity induced by phytoplankton. In this study, they report that the larval weight of pike is lower in turbid water, despite that pike larvae spend less time in vegetation and attack more prey. Thus, both direct (i.e. feeding and habitat choice) and indirect qualities (i.e. weight) of pike larvae are affected by the

330 habitat quality (macroalgal structure, turbidity) and therefore probably also larval 331 survival and recruitment to the adult population (Engström-Öst et al. 2007, Engström332 Öst and Mattila 2008). 
In a case study comprising the entire Finnish coastline, Uusitalo et al. (2012) used a

335

Bayesian network model (expert driven model structure, data-learned parameters) to study the effects of many different factors (N, P, chlorophyll $a$, duration of ice coverage in winter, shore density in the area and salinity) on the CPUE (of reported commercial catches). Shore density was defined as the length of the shoreline within a rectangle, measured from the basic water level line from a 1:20 000 map and divided by the area of water surface in the rectangle (in ha), and it reflected the availability of coastal areas in the rectangle. The tested fish species were among others: pikeperch, pike, perch, flounder (Platichthys flesus), Baltic herring, burbot (Lota lota) and smelt. In their study, Uusitalo et al. (2012) report that shore density is the most influential factor. The strongest effects occur for pike, although it is concluded that shore density, corresponding closely to the availability of coastal EFH, is an important factor for all species, despite the fact that many of them are essentially freshwater ones, whose distribution also can be limited by salinity.

With regard to the importance of coastal EFH for production and viability of flounder, there are a number of case studies available from the Baltic Sea. In a study from Latvia, Ustups et al. (2013) utilized data spanning over 30 years to demonstrate that the spawning habitat (available water volume suitable for reproduction with regard to oxygen conditions) positively affects the survival and abundance of flounder larvae. Still, recruitment does not correlate with the supply of larvae, suggesting the presence of a bottleneck in the availability of juvenile growth habitat, which in itself, is also coastal. Case studies from southern Finland used fishery-independent data on adult flounder as well as historical and present-state data on juveniles in shallow coastal areas. These studies show that a pronounced decrease in abundance of juveniles correlates with an 
increased bottom coverage of filamentous algae. A simultaneous decrease in the

360 abundance of the adult stock indicates that a decline in the availability of EFH for

361 juveniles acts as a bottleneck for the flounder population (Jokinen et al. 2015, 2016),

362 supporting the conclusions of Ustups et al. (2013). Similar results have also previously

363 been demonstrated by Pihl et al. (1994) and Carl et al. (2008) in the Kattegat and by

364 Florin et al. (2009) for the Baltic Sea, but in the latter study more clearly for turbot

365 (Scophthalmus maximus) than for flounder. The results for flounder above are further

366 supported by Orio et al. (2017) who modelled spawning areas of flounder at a Baltic-

367 wide scale and recognise a positive correlation between flounder spawning areas and

368 adult stocks. The findings by Ustups et al. (2013) and Orio et al. (2017) are included as

369 direct evidence in Table 1, although like the case with cod above, these results are not

370 fully "coastal".

For pikeperch in the German area of the Baltic Sea, the population size is strongly connected with the occurrence of suitable spawning sites in the inner coastal waters with lower salinities around 5-6 (Winkler 1996). These EFH are the base for nearly 40\% of the total annual catch of pikeperch in German coastal waters with higher salinities (around 10) and corresponding numbers, or $44 \%$, can be shown for roach (Winkler et

For pike, Nilsson et al. (2014) show an increased recruitment of juveniles in three coastal wetlands of SE Sweden which have been restored in different ways. In areas with 381 temporally flooded terrestrial vegetation, the migration of pike juveniles is shown to increase from a few thousand individuals in previous years to $>100,000$ individuals after 
384 effects (Fredriksson et al. 2013).

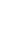

stocks in coastal areas remains to be clarified, although there are indications of positive

Finally, some species utilize both coastal habitats, coastal wetlands and rivers for spawning and may display sympatric, genetically isolated populations. While their juvenile and adult stages may occur in the same habitats, spawning takes place in either fresh or brackish waters (Westin and Limburg 2002, Wastie 2014). The relative proportions of these sympatric populations may differ between areas and through time. In case studies from Estonia and Sweden, the relative importance of fresh or brackish water recruitment areas (spawning habitat preferences) for brackish water fish populations was examined through the use of otolith $\mathrm{Sr}$ :Ca profiles. These studies demonstrate the importance of coastal wetlands and rivers as spawning habitats for (semi-)anadromous fish as pike (Engstedt et al. 2010, Rohtla et al. 2012), burbot and ide (Leuciscus idus) (Rohtla et al. 2014, 2015). In the Väinameri Sea area in Estonia, 90\% of adult pike hatches in fresh water and only $10 \%$ in brackish water (Rohtla et al. 2012; Rohtla 2015). In Sweden, 20\% of pike hatches in brackish water in the Forsmark area at the $60^{\circ} \mathrm{N}$ latitude and $80 \%$ hatches in brackish water in the Kalmar Sound at the $56^{\circ} \mathrm{N}$ latitude (Engstedt et al. 2010). When compared with older (observational or anecdotal) data, the Estonian results suggest that brackish-water spawning pike is becoming rarer, which may be a result of deteriorated brackish water spawning grounds (Rohtla 2015). Along the Estonian coastal area, Rohtla et al. (2017) further demonstrate, also through the use of otolith chemistry techniques, that brackish water spawning whitefish has become rarer, which probably also reflects a poorer ecological status of its coastal spawning areas. Similarly, Byström et al. (2015) notice an important role of freshwater 
habitats for perch recruitment in a Swedish coastal area with high abundance of the three-spined stickleback, which may prey on early life stage perch.

\subsubsection{Means to increase the knowledge of the importance of coastal EFH}

Although many different coastal habitats are essential for fish production and for the provisioning of rich fish communities in the Baltic Sea, the establishment of direct/quantitative relationships demonstrating their actual role for fish production is still in its infancy. The relatively low number of studies explicitly dealing with the importance of EFH for fish stocks is somewhat surprising. For many species, too little seems to be known about the ecology of the species in order to assess whether habitats are actually essential and limiting the production and viability of the populations (Levin and Stunz 2005, Seitz et al. 2014). Better evidence is, however, often found for nonmigrating coastal species compared to migrating species (Iles and Beverton 2000), with cod (Hinrichsen et al. 2017) and the demersal ecotype of flounder (Orio et al. 2017) as possible exceptions. This could potentially be due to the conservative nature in habitat

429 choice of non-migratory fish, or simply that it is easier to detect fish-habitat 430 relationships in studies where many geographically restricted populations are included. 
In other cases, indirect evidence exists or data for quantitative examination of the importance of coastal EFH for fish stocks may already be available and additional analyses could contribute to pinpoint their ecological importance (Pulkkinen et al. 2011,

Kraufvelin et al. 2016). In a recent paper, Macura et al. (2016) present a methodological

436 protocol for conducting a systematic review mainly on the impact of anthropogenic-

437 induced physical and structural habitat changes on fish recruitment in shallow

438 nearshore areas. Such a protocol can be used to assess the importance of undamaged

439 coastal EFH for fish production. Further evidence on the role of coastal EFH can also be

440 achieved using spatial approaches (e.g. assessing relationships between habitats of

441 juveniles and adult fish to detect bottlenecks in early life stage), temporal data analyses

442 (e.g. assessing variability between years in success of different life stages), stage-

443 structured modelling (assessing habitat specific survival in stage-structured models) or

444 otolith chemistry techniques (comparing contribution of different habitats through

445 "fingerprinting" of different juvenile habitats). Currently, the most promising approach

446 may be to estimate habitat-specific demographic rates in stage-structured modelling

447 (Levin and Stunz 2005, Vasconcelos et al. 2014). It is then important, however, to

448 combine this approach with habitat maps to quantify the importance of different

449 habitats. When used properly, this approach may identify low productivity (per unit

450 area) habitats as important, if they are abundant enough, compared to very productive

451 habitats that are scarcer.

It should also be stressed that the establishment of a link between coastal EFH and 454 fish stocks may not always be the prime interest as this is sustained already by the 455 definition of EFH and the fact that a fish population is viable. Instead, the importance of 456 EFH utilised by a population throughout different life history stages should maybe be 
the centre of attention. This, in turn, leads to the question of "overlapping" EFH in a

458

459

460

461

462

463

464

465

466

467

468

469

470

471

472

473

474

475

476

477

478

479

480

481

region or an area, and as a consequence, the difficulties to separate the relative effects or

importance of different EFH (spawning, nursery, feeding, etc.) for a fish population and how "sub-EFH" are inter-linked and connected in the context of spatial/landscape ecology (Rose 2000, Levin and Stunz 2005, Vasconcelos et al. 2014).

(1) 
482

483

484

485

486

487

488

489

490

491

492

493

494

495

496

497

498

499

500

501

502

503

504

505

506

subjected to environmental pressure could be pivotal for the future potential of the

Baltic Sea to provide ecosystem goods and services (Holmlund and Hammer 1999, Rönnbäck et al. 2007, Ahtiainen and Öhman 2014, Uusitalo et al. 2016).

As a spatial representation for weighing large numbers of cumulative anthropogenic impacts against ecosystem components and describing the current condition of various part of the sea area, the Baltic Sea Impact Index has been developed (see Halpern et al. 2008, HELCOM 2010, 2017 and table 2 in Korpinen et al. 2012 for details). This index shows that the lowest cumulative impact is generally found in the Gulf of Bothnia in the sparsely populated northernmost part of the Baltic Sea, and the highest impacts mainly occur in the coastal areas of the Finnish south and southwest, along the Estonian northern and western coast, along the east and west coast of southern Sweden, in the Polish Bay of Gdansk and in the Danish and German parts of the Baltic Sea (Figure 2). This impact map may be regarded as closely reflecting the general pressures on coastal EFH, as well.

Eutrophication, coastal construction and development, climate change, invasive species and fisheries have been acknowledged as major human-induced threats to coastal EFH in general (Jackson J.B.C. et al. 2001, Kappel 2005, Powers et al. 2005, Orth et al. 2006, HELCOM 2010, Hansen and Snickars 2014, Seitz et al. 2014, Sundblad and Bergström 2014, Kraufvelin et al. 2016). A specific feature and a natural threat to coastal EFH in the Baltic Sea is the post-glacial land-uplift process, which naturally, but constantly, shapes and alters the coastline and its shallow habitats for instance when semi-isolated flads and bays turn into freshwater ecosystems (Snickars et al. 2009, Meriste and Kirsimäe 2014). Among the human-induced threats, physical pressures 
507 such as trawl fishery, shipping and boat traffic with the required infrastructure in the 508 form of dredging, and shoreline modifications generally cause direct impacts on the

509 habitats and are hence - in theory - easier to manage (Eriksson et al. 2004, Sandström et 510 al. 2005, Sundblad and Bergström 2014, Pommer et al. 2016). Other (non-physical)

511 threats/pressures usually act more indirectly and are hence often more challenging to 512 manage (Elliott 2010, Duarte 2014). Most human-induced threats are severe on their

513 own, but often have their largest impact when acting additively and synergistically

514 (Elliott 2004, McLusky and Elliott 2004, Crain et al. 2008). Fish communities are affected

515 both directly when exposed to these threats and indirectly through fragmentation,

516 deterioration and loss of habitat. Here, the distinction between different fish species

517 must again be stressed as for instance 


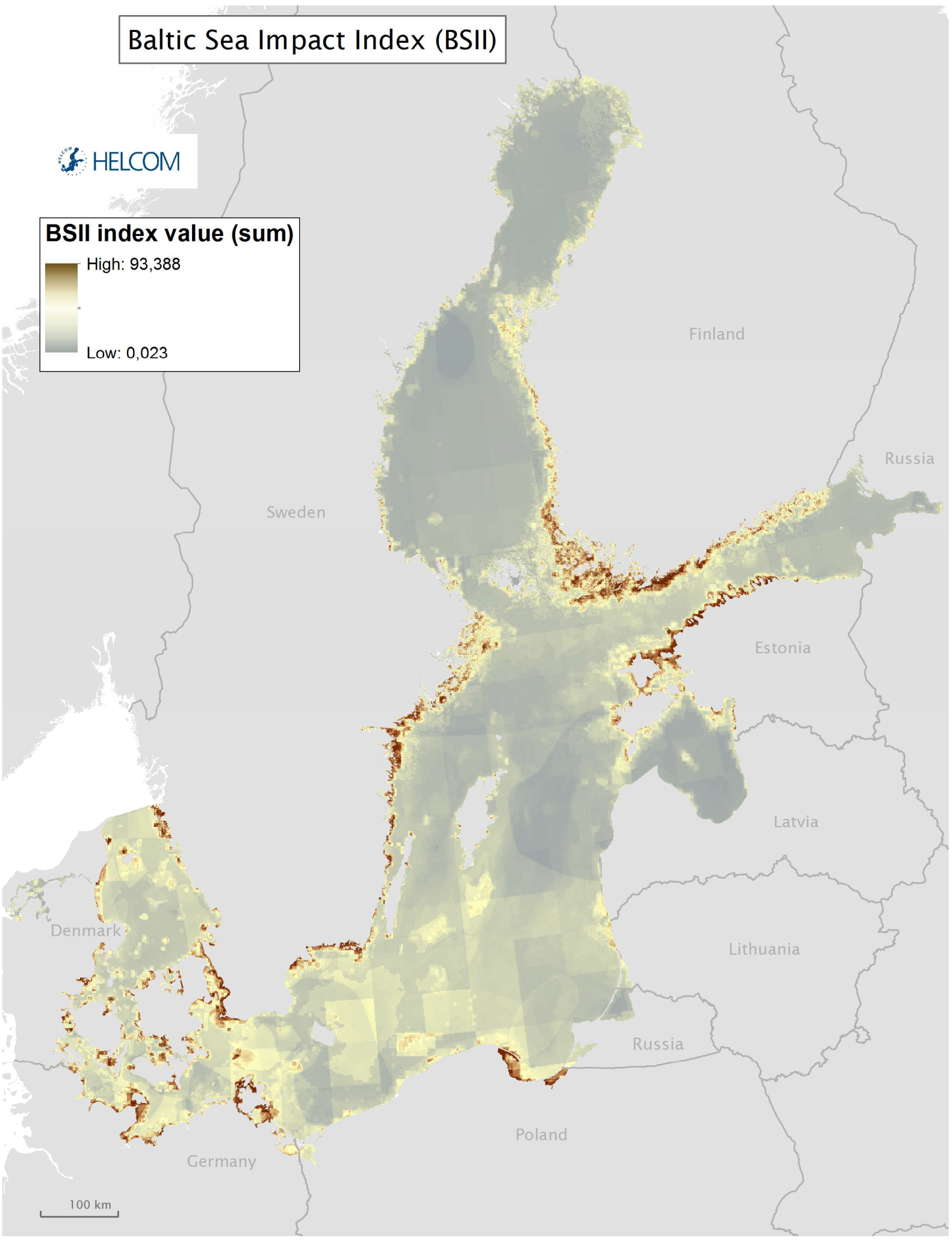

Figure 2. Presentation of cumulative potential anthropogenic impacts by the Baltic Sea Impact Index in $5 \mathrm{~km} \times 5 \mathrm{~km}$ assessment units. The index in each assessment unit consists of the sum of anthropogenic impacts on selected ecosystem components present in the unit. The original index formula is from Halpern et al. (2008) and Korpinen et al. (2012). The map is taken from HELCOM (2017), with permission. 
mesopredatory fish, such as cyprinids and sticklebacks, may benefit from some of these threats/pressures or the negative effects of the threats/pressures imposed on other fish species (see e.g. Persson et al. 1991, Sandström and Karås 2002, Bergström et al. 2015, Byström et al. 2015). This may also be the case, to some extent, for pikeperch, which seems to be benefitting from coastal eutrophication and warmer summers (Heikinheimo et al. 2014) and also for the non-indigenous round goby Neogobius melanostomus (Ojaveer et al. 2015).

\section{From a strict habitat perspective, there are some inherent differences with regard to} which threats/pressures are the most dramatic ones for coastal EFH in the Baltic Sea. Seagrass and macrophyte beds are threatened by anthropogenic factors such as poor water quality caused by pollution, eutrophication, dredging, excessive sedimentation, altered openness of sheltered bays to the sea, climate change (leading to increased land runoff) and coastal development (Hemminga and Duarte 2000, Idestam-Almquist 2000, Airoldi and Beck 2007, Snickars et al. 2009, 2015, Rosqvist et al. 2010). Perennial macroalgal belts are threatened by eutrophication processes increasing the abundance of ephemeral algae, that suppress or inhibit the recolonization of canopy-forming algae and other organisms (Thompson et al. 2002, Råberg et al. 2005, Korpinen et al. 2007, Kraufvelin et al. 2007, 2010), but also by human construction and urbanization affecting water movement, water quality and causing habitat-related changes (Vogt and Schramm 1991, Eriksson et al. 1998, Kraufvelin 2007, Kraufvelin et al. 2010). Mussel beds are threatened by eutrophication, pollution, sedimentation, invasive species (e.g. the round goby), destructive fishing practices, and processes connected with climate change, such as higher water temperatures, acidification, increased storminess, increased land run-off and decreased salinity (Thompson et al. 2002, Airoldi and Beck 2007, Rakauskas et al. 
551

552

553

554

555

556

557

558

559

560

561

562

563

564

565

566

2013, Díaz et al. 2015). Some of these pressures may, however, sometimes also prove to be beneficial, for instance for blue mussels (Mytilus trossulus) when new settlement areas are provided or when there are moderate increases in water movement (Díaz et al. 2015) and in temperature levels seasonally (Widdows 1991). The information on current threats to sedimentary environments, finally, is quite scarce (Brown and McLachlan 2002), but the major pressures on these habitats consist of the construction and use of marinas and ship ways including dredging, extraction of sand or gravel, trawl fishery, eutrophication, tourist developments, pollution from sewage discharge and industries as well as aquaculture activities (Newell et al. 1998, Airoldi and Beck 2007).

Thus, not all coastal EFH are affected by exactly the same threats, nor do they respond in the same way to similar pressures. All the human activities mentioned above are involved in causing different types of pressures and impacts on the habitats e.g. anoxic conditions in estuaries and enclosed basins (Karlson et al. 2002), accumulation of drifting algae (Vahteri et al. 2000), long-term accumulation of contaminants (Islam and Tanaka 2004) and introduction of non-indigenous species (Leppäkoski et al. 2002, Katsanevakis et al. 2014, Ojaveer and Kotta 2015). For more detailed information on species and habitats in the north-eastern Atlantic, see http://www.marlin.ac.uk/. Exclusively for the Baltic Sea, this kind of information is being gathered within HELCOM (http://www.helcom.fi/) and at a national level at least in Finland (http://paikkatieto.ymparisto.fi/velmu/).

(1) 


\subsection{Case studies about threats to and pressures on coastal EFH}

Eutrophication favours the production of fast-growing, short-lived benthic and planktonic algae, that alters the structure and function of marine habitats and may cause hypoxia when accumulated and broken down (Lundberg 2005, Conley et al. 2009, Kraufvelin et al. 2010, Paerl and Otten 2013). This human pressure is acknowledged as a major problem to coastal EFH all over the Baltic Sea (HELCOM 2010, 2017, Kraufvelin et al. 2016). The large-scale decrease in distribution of the macroalga bladderwrack in eastern Sweden and southwestern Finland at the deeper end of its depth limit is of specific relevance for this study. This bladderwrack habitat loss is mainly caused by eutrophication-related processes in form of decreased light penetration and hampered recruitment and growth due to competition with filamentous algae and sedimentation (Kautsky et al. 1986, Korpinen et al. 2007, Kraufvelin et al. 2007, Rinne et al. 2011). As a consequence of this, large areas of shallow waters, potentially valuable for coastal fish, have been lost (Kautsky et al. 1986, Bergström et al. 2013, Vahteri and Vuorinen 2016). Similar patterns were also found in the shallow Puck Bay in Poland (Plinski and Florczyk 1984, Ciszewski et al. 1992, Węsławski et al. 2009), although this area is now slowly recovering (Węsławski et al. 2013). Another typical phenomenon due to eutrophication is the reed belt overgrowth of lagoons, sheltered bays and river mouths (Pitkänen et al. 2013, Altartouri et al. 2014, Meriste and Kirsimäe 2014). This process is potentially making shallow areas less useful as habitats for fish (Kneib and Wagner 1994, Weinstein and Balletto 1999), although see also Härmä et al. (2008), Lappalainen et al. (2008), Snickars et al. (2010) and Nilsson et al. (2014) for some positive influences of reed vegetation on fish communities, especially pike, but also for perch. Probably, too widespread and compact reed belts are negative for fish, while more restricted belts, and 
600

601

602

603

604

605

606

607

608

609

610

611

612

613

614

615

616

617

618

622

belts from the previous season that have been flattened from ice and waves as well as the outer edges of reed areas are generally positive for fish (Lappalainen et al. 2008).

Eutrophication is also often acting in concert with other pressures such as coastal construction, seabed disturbance, climate change, overfishing and species introductions (Lundberg 2005) and understanding relationships between ecosystems and multiple human-induced pressures acting simultaneously is indeed a major challenge within marine environmental management (Borja 2014, Borja et al. 2016). Eutrophication combined with mesopredator release due to overfishing of large piscivorous fish species constitutes an example of a cumulative pressure, which can have strong effects on coastal EFH and present extensive challenges for management (Eriksson et al. 2009, 2011, Östman et al. 2016, Uusitalo et al. 2016). Eutrophication combined with the presence of invasive species can also impose interactive pressure on coastal EFH, as in the case with the recent invader in the northern Baltic Proper, Harris mud crab, Rhithropanopeus harrisii, occurring in both bladderwrack (Jormalainen et al. 2016) and eelgrass beds (Gagnon and Boström 2016) in the Finnish Archipelago Sea and in boulder fields with bladder-wrack (Nurkse et al. 2015) as well as in un-vegetated soft bottom areas in Estonia (Lokko et al. 2017). This invader acts as a mesopredator and can strongly reduce the number of grazers and impair their capability to buffer excessive growth of filamentous algae leading to decreased biodiversity and lowered habitat quality. Eutrophication effects combined with coastal construction dampening wave action can be exemplified by Kraufvelin et al. (2010) who conducted long-term experiments in outdoor rocky shore mesocosms. Kraufvelin and colleagues show that a combination of high nutrient enrichment with $50 \%$ lowered wave action over two years lead to a 2.5-fold reduction of habitat-forming perennial brown algae (mainly of the 
625

626

627

628

630

631

632

633

634

635

636

637

638

639

640

641

642

643

644

645

646

647

648

649

order Fucales) and an 80-fold increase in annual green algae (mainly of the order Ulvales).

The physical pressure from human activities is both high and increasing in the coastal zone, especially in the shallowest areas and habitats (Sundblad and Bergström 2014). Activities such as recreational boating, building of marinas and other forms of construction constitute major problems for coastal EFH all over the Baltic Sea, but perhaps currently to a higher extent in Sweden, Finland, Poland, Germany and Denmark than in Estonia, Latvia and Lithuania (HELCOM 2010, Dafforn et al. 2015, Kraufvelin et al. 2016). In the Stockholm archipelago of Sweden, Sundblad and Bergström (2014) used predictive habitat modelling and mapping of human pressures to estimate the cumulative long-term effects of coastal development in relation to fish habitats. The results suggest an annual increase in the proportion of degraded areas of $0.5 \%$ on average and of $1 \%$ for areas close to larger human population centres. Furthermore, the same study shows that approximately $40 \%$ of available habitat for pike, perch and roach was already subject to some form of construction by 2005 (Sundblad and Bergström 2014).

In Estonia, Latvia, Lithuania and Poland, invasive species are, apart from eutrophication, brought forward as important human-induced threats to coastal EFH (HELCOM 2010, Kraufvelin et al. 2016). Among invasive species, the round goby has been of increasing importance during the last years (Ojaveer et al. 2015, Kotta et al. 2016) with potential to impact the distribution of EFH in the form of blue mussel beds (Järv et al. 2011, Kornis et al. 2012, Rakauskas et al. 2013). Round gobies generally prefer hard bottom habitats, where mussels make up its most important food source 
(Barton et al. 2006, Karlson et al. 2007, Järv et al. 2011, Kornis et al. 2012, Rakauskas et

al. 2013), although Nurkse et al. (2016) characterize the species as a generalist consumer. Due to competition with round gobies, it has also been shown that juvenile turbot change their diet and turbot recruitment simultaneously decreases significantly (Ustups et al. 2016). Round gobies may also, through competition for food and habitat, negatively affect flounder (Karlson et al. 2007, Järv et al. 2011, Orio et al. 2017), ruffe Gymnocephalus cernua (Rakauskas et al. 2013), and viviparous eelpout Zoarces viviparus (https://www.nobanis.org/marine-identification-key/fish/fish-start/fishkey/neogobius-melanostomus/). The effects of invasive species increase as the populations establish and spread to adjacent areas as can be seen with the round goby in the southwestern Baltic Sea (Azour et al. 2015). The round goby may, however, not only influence the biological communities of the Baltic Sea negatively. Recent studies from the northeastern German coast (Oesterwind et al. 2017) and from Estonia (Liversage et al. 2017) show that the round goby is included in the local food web, 664 including fish eating birds.

In Germany, Denmark and on the southern and southwestern coast of Sweden, major human-induced threats to coastal EFH are, in addition to eutrophication and climate change, coastal construction, demersal trawling, tourism, dredging and material extraction (HELCOM 2010, Kraufvelin et al. 2016). Material extraction, e.g. extensive

670 removal of stones and boulders in coastal areas of Denmark has not only led to 671 destruction of reefs and removal of hard bottom habitat, but also to the loss of biogenic 672 structures associated with and characteristic of these reefs (Carr 1994, Dahl et al. 2008). 673 Støttrup et al. (2014) studied a re-established stony reef in Kattegat and documented an 674 increase in fish abundance and can thereby demonstrate that these damages may be to 
675

676

677

678

679

680

681

682

683

684

685

686

687

688

689

690

691

692

693

694

695

696

697

698

699

some extent reversible. Also, bottom trawling in the Kattegat has led to a decrease in hard bottoms in general through removal of stones and boulders (homogenisation of mixed bottoms) and to a decrease in the amount of sensitive species, some of which are habitat-forming (Hopkins 2003, Pommer et al. 2016).

Interestingly, despite many scientists mentioning climate change as a major threat to coastal EFH in their regions (Kraufvelin et al. 2016), there are still few studies from the Baltic Sea that explicitly focus on climate change related effects on EFH. This is surprising as many different pressures in the Baltic Sea fall under the climate change umbrella such as increased temperatures, decreased salinity, decreased oxygen concentrations, acidification, increased storminess, increased sea levels, etc. (BACC Author Team 2008, HELCOM 2013). There are, however, some references available that are related to effects on coastal EFH, e.g. for macrophytes from the Baltic Proper (Idestam-Almquist 2000, Härmä et al. 2008), for perennial bladderwrack from the Baltic Proper and from the southwestern Baltic Sea (Kraufvelin et al. 2012, Graiff et al. 2015, 2017), for blue mussels from the southwestern Baltic Sea (Thomsen et al. 2010, Havenhand 2012), and for fish and zoobenthos from the entire Baltic Sea (MacKenzie et al. 2007) and from the Baltic Proper (Snickars et al. 2015), although most of the reported and projected habitat effects in these studies are rather minor ones.

To better quantify and evaluate the magnitude of all threats to and pressures on coastal EFH highlighted in the case studies above and to provide more accurate and reliable information and recommendations for the management and conservation of EFH in a Baltic Sea wide perspective, maps of pressure variables, together with a mechanistic understanding of habitat effects of different threats/pressures, need to be 
700 integrated with habitat maps. For these kinds of purposes, web-based knowledge

701 platforms such as the one developed by MarLin for the UK (http://www.marlin.ac.uk/)

702 can be utilized and applied. An attempt in this direction has also been done by HELCOM

703 (2010) and Korpinen et al. (2012), as may be seen in Figure 2 of this review. More recent

704 web resources can be found in HELCOM HOLAS II (http://helcom.fi/helcom-at-

705 work/projects/holas-ii/, see also HELCOM 2017) and the associated HELCOM TAPAS

706 (http://helcom.fi/helcom-at-work/projects/tapas). A promising approach to assess

707 habitat quality based on the ecological status of benthic indicators and the EU Habitats

708 Directive (Anon. 1992) has also recently been presented for Estonian waters by Torn et

709 al. (2017) and similar approaches could be further developed for other regions of the

710 Baltic Sea. Another way forward could be to combine probabilistic Bayesian network

711 models describing the complex relationships between human activities and sensitive

712 ecosystem components (e.g. sensitive habitats), with GIS databases (Stelzenmüller et al.

713 2010, Helle et al. 2016).

714

715

716

717

718

719

720

721

722

723

724 


\section{INTEGRATED MANAGEMENT AND CONSERVATION OF COASTAL EFH IN} THE BALTIC SEA

729

730

731

732

733

734

735

736

737

738

739

740

741

742

743

744

745

746

747

748

749

The increasing anthropogenic impacts on marine waters have fuelled the discussion on how to manage and to conserve marine resources sustainably. During the last decade, there has been a raised focus on ecosystem-based management of marine ecosystems to secure the maintenance of healthy, productive, and resilient ecosystems capable of providing the services needed for the well-being of society (Collie et al. 2013, YáñezArancibia et al. 2013, Borja 2014, Andersen and Kallenbach 2016, Borja et al. 2016). Within the Baltic Sea region, the current leading directives and agreements for this are the EU Marine Strategy Framework Directive (MSFD; Anon. 2008), the HELCOM Baltic Sea Action Plan (BSAP; HELCOM 2007) and the Common Fisheries Policy (CFP; Anon. 2013), but also the EU Habitats Directive (HD; Anon. 1992), the EU Water Framework Directive (WFD; Anon. 2000) and the EU Maritime Spatial Planning Directive (MSPD; Anon. 2014) are important.

Although both healthy fish populations and benthic habitats are central elements for maintaining a good status of the coastal environment, management of fisheries and nature conservation have historically been separated in the Baltic Sea region like in many other parts of the world (Sissenwine and Symes 2007, Kenny et al. 2009, Kraufvelin et al. 2016). The awareness of potential synergies between the two has also been low. Traditional management of marine resources has typically ignored interactions between fisheries and the status of coastal habitats, cross-system fluxes, 
750

751

752

753

754

755

771 covered by the Habitats Directive (Anon. 1992) and the European and national IUCN

772 red-lists

773 (http://ec.europa.eu/environment/nature/conservation/species/redlist/index en.htm, 
774 Kraufvelin et al. 2016). Sundblad et al. (2011) investigated the representativity and

775

776

777

778

779

780

781

782

783

784

785

786

787

788

789

790

791

792

793

794

795

796

797

798

connectivity of Marine Protected Area (MPA) networks in the northern Baltic Proper

(Sweden and Finland) with respect to a coastal fish assemblage and associated habitats based on fish distribution maps and the linking of specific life stage occurrences to environmental variables. These analyses reveal that both the representativity and the connectivity of the network are poor as only $3.5 \%$ of the assemblage recruitment habitat is protected and $48 \%$ of potentially connected habitats are included in the MPA network. Furthermore, from a coastal EFH perspective, it appears that the most relevant areas are not always the ones being preserved. The lack of an ecosystem-based management perspective and the traditional split of fisheries and environmental management have again been major reasons underlying the poor conservation status of EFH in the Baltic Sea. Further challenges to the management of fish and habitats in the coastal zone are that they are under national jurisdictions of ten different countries in the Baltic Sea area, which cause large practical differences in management regimes. Hence, the authors see a need for the EFH perspective to be more strongly considered at both national and international levels of coastal management and conservation. Currently, changes appear to be taking place in many countries around the Baltic Sea (Kraufvelin et al. 2016) so now would be an opportune time for science advisors to bring EFH to the forefront of policy makers' attention.

In order to aid in merging the management of fisheries and environmental issues, there is a general need for a common awareness of the importance of coastal EFH and also about the threats to these habitats among managers, politicians and the public (e.g. Lotze 2004). There has been an apparent lack of information on the importance of the habitats for fish production and viability, but also previously a lack of maps depicting 
the spatial distribution of specific types of coastal EFH to be used in marine spatial planning, permitting processes and for other management purposes. To that end, there is also a great need for more species- and life-stage-specific knowledge, both in terms of population-level effects and the geographical distribution of coastal EFH. As quantitative evidence for habitat limitation of fish production is slowly accumulating from different areas and species through the use of various methods (Vasconcelos et al. 2014, Seitz et al. 2014), the possibilities for integrating fish habitats in fisheries management and nature conservation will improve accordingly.

In order to reach a higher level of protection of coastal EFH, the role of habitats in supporting fisheries must also be disentangled in a broader context so that the value of the ecosystem services that these habitats provide can be emphasized more strongly (Holmlund and Hammer 1999, Rönnbäck et al. 2007, Uusitalo et al. 2016). These services may include producing fish for commercial and recreational fisheries, aquaculture and biological regulation (e.g. regulation of eutrophication symptoms through top-down control of filamentous algae), but also maintenance of biodiversity and ecosystem resilience. Many habitats considered EFH are also of importance for coastal protection against erosion, as nutrient filters, carbon sinks and for human recreation and scientific, educational and cultural purposes (Ahtiainen and Öhman 2014, Bouma et al. 2014, Ivarsson et al. 2017). Natural scientists together with environmental economists and social scientists should therefore consider all the ways in which coastal fish habitats provide value to society and use these as examples in communicating the needs for protection of coastal EFH and their sustainability (Støttrup et al. 2016). In this context, the general protection of coastal EFH from diverse pressures and what level of sustainable use that can be permitted should also be clearly stated 
824 (Turner et al. 1999, Fluharty 2000). This information can be included in utility functions

825 of decision support tools and in that way be accounted for when the performance of

826 alternative management strategies/actions are evaluated quantitatively (see Laurila-

827 Pant et al. 2015).

828

In the process of developing an efficient management scheme for the protection of coastal EFH, merging the objectives of fisheries and environmental management, possible difficulties of a common management of habitats and fish must be taken into careful consideration (Rose 2000, Rice 2005). Most exploited fish are long-lived, utilise many different habitats during their life cycle, and often exhibit large fluctuations in

834 abundance. Efficient management therefore requires understanding how environmental 835 variability, due to both natural and anthropogenic sources, affects fish population 836 dynamics. Rose (2000) described a number of issues that are related to quantifying

837 effects of environmental quality on fish populations and which at the same time may 838 serve as demonstrations of how modelling could be used to address them. These issues 839 include difficulties with the detectability of relationships, uncertainties due to 840 heterogeneity in the habitat and disproportional population responses, unnecessary 841 sacrifice of biological realism, neglected significance of community interactions, and 842 ignored sublethal and cumulative effects. The quantification of effects of environmental 843 quality on fish populations can be improved if these issues are carefully considered in 844 the analyses, and by adopting multidisciplinary approaches that combine stage845 structured modelling and life history theory (Rose 2000, Levin and Stunz 2005, 846 Vasconcelos et al. 2014). 
Finally, the need to combine alternative management strategies or actions and the objectives of the society, i.e. decision-making criteria against which success or failure of management are to be evaluated, should also be explored. Laurila-Pant et al. (2015) discuss these issues in connection with criteria setting towards a more holistic

852 framework, although mainly with focus on biodiversity-related objectives. From a risk management perspective, approaches based on the precautionary principle may also sometimes be needed (Long et al. 2015, Chapman 2017). This, because uncertainty and lack of sufficient evidence are not acceptable reasons for not protecting supposedly essential habitats, if losing them may cause the collapse of fish stocks, with effects potentially propagating throughout food webs. Another issue which may complicate

858 joint management is the inconsistency in the definition and understanding of the term 859 habitat and habitat-related concepts in general (Elliott S.A.M. et al. 2016). It will not be 860 dwelled further into habitat definitions in this review, but according to Elliott S.A.M. et al. (2016), unclear use of habitat-related terminology could have implications for the 862 effectiveness of ecosystem-based fisheries management when e.g. different actors 863 within marine science use the same terms with different connotations. However, when coastal management is implemented at local scales, the inclusion of all stakeholders

865 from an early stage can go some way to mitigate such incommensurable language 866 barriers and potential miscommunication (Hopkins et al. 2011). 
873

874

875

876

877

878

879

880

881

882

883

884

885

886

887

888

889

890

891

892

893

894

895

896

897

\section{SYNTHESIS}

Coastal EFH form elementary cornerstones of the Baltic Sea ecosystem due to the central importance of fish for ecosystem functioning and the dependence of fishes upon specific coastal habitat types. As such, there are strong needs to focus on the protection of coastal EFH in addition to increasing our understanding of their species-specific importance, and on disentangling causal factors, pressures and mechanisms behind the changes that are observed in their status. Efficient management measures can be developed based on improved knowledge of causal factors and mechanisms for ecosystem change, e.g. how various stressors interact to structure communities (e.g. Rose 2000). The same applies to monitoring, assessing and mapping the availability and the state of coastal EFH as well as the documentation of human activities and pressure variables related to them (HELCOM 2010, Kraufvelin et al. 2016). Initial steps to bring this work forward could be to construct roadmaps, focus on directed studies and develop and harmonize the methodology (Kraufvelin et al. 2016). During this process, there will be evident needs for intensified cooperation between the Baltic Sea countries in order to reach successful implementations of international agreements and legislative marine acts such as the Baltic Sea Action Plan (BSAP), the Habitat Directive (HD), the 
898 Marine Strategy Framework Directive (MSFD) and the Marine Spatial Planning Directive 899 (MSPD). At the same time, local/regional conditions and the actual characteristics of the 900 targeted ecosystems need to be taken into consideration more efficiently, because, as it 901 has been shown in a number of cases in this review, the most efficient management may 902 sometimes benefit from being planned and implemented case-specifically.

903

904

A major underlying objective for developing a more efficient management 905 framework should be to improve the possibilities for connecting fisheries and 906 environmental management across sectors (Pikitch et al. 2004, Thrush and Dayton 2010). Efforts made in these directions will also simultaneously aid in improving the sustainability of coastal EFH, enhance our abilities to predict and mitigate current and 909 future effects of environmental change as well as support activities to create and 910 implement adaptive management plans. To increase the awareness of the benefits of 911 integrating management of fish and habitats, the scientific community can contribute in 912 many ways. Ecological synergies achieved by protecting coastal EFH can be 913 demonstrated; methods for large-scale mapping of EFH can be developed and utilized; 914 effects of different threats to EFH may be quantified; and the importance of the habitats 915 may be communicated (Kraufvelin et al. 2016). However, since not all habitats can be 916 conserved or restored, some general frameworks to prioritize critical habitats of e.g. 917 exploited fishes or red-listed species need to be developed and followed (Rose 2000). It 918 must also be kept in mind that if a specific fish habitat is not strictly limiting population 919 growth, a change in its availability does not lead to a change in stock sizes, provided that 920 other regulating factors remain constant (Levin and Stunz 2005, Rice 2005). 
This review gives an overview of the current knowledge as well as the lack of knowledge about coastal EFH in the Baltic Sea and brings about some suggestions for future work and cooperation. The topic is timely and of high importance in the current era of rapidly improving habitat modelling, new demands for better monitoring of marine ecosystem such as BSAP (HELCOM 2007), MSFD (Anon. 2008) and MSPD (Anon. 2014), and the findings that the Baltic network of MPAs cannot be considered ecologically coherent (Sundblad et al. 2011). The review also stresses the importance to

929 protect key habitats vital for the survival of early life stages of fish and to map these areas (Kraufvelin et al. 2016). Apart from the need for conducting more investigations

931 into the topics mentioned above, further studies also seem to be especially urgent within 932 the field of attaining quantitative data for the value of coastal EFH for fish production, 933 including defining the key habitats for protection and for possible restoration efforts, as 934 well as disentangling the major threats/pressures and their effects (e.g. Elliott 2004, 935 Elliott, M. et al. 2016). Improved integration of habitat quality in fish stock assessment 936 and ecosystem-based fishery management is also warranted when this path is followed 937 (Seitz et al. 2014, Sundblad et al. 2014). A crucial part of this work could consist of 938 carrying out additional analyses on existing data as a lot of the needed information 939 already seems to be available through monitoring and mapping work carried out in 940 Baltic Sea countries (Kraufvelin et al. 2016). During this process, the utilization of meta941 analytical approaches could be worth considering (see e.g. Pulkkinen et al. 2011, Östman 942 et al. 2016). The initiation of common research projects and intensified outreach efforts 943 constitute fruitful ways to bring this work forward on a Baltic-wide scale. In order to 944 succeed with all these undertakings, devoted endeavours focusing on all aspects of 945 coastal EFH will be of utmost importance. Successful implementation of these activities 
946 will then in turn hopefully lead to clear and lasting improvements for fish and their

947 habitats in the entire Baltic Sea region.

948

949

950

951

952

953

954

955

\section{ACKNOWLEDGEMENTS}

956

957 This review has been prepared on the basis of information collected and discussed

958 during a workshop, 'Essential Coastal Habitats for Fish', in Öregrund, Sweden during

959 June $2^{\text {nd }}-4^{\text {th }} 2015$, gathering together 30 national experts from eight Baltic Sea

960 countries. The workshop and preparation of the review article was funded by the Nordic

961 Council of Ministers to Jens Olsson at Swedish University of Agricultural Sciences. The

962 funding source had no practical involvement in the work carried out for the review 963 article.

964

965

966

967

968

969

970 


\section{REFERENCES}

982

983 Ahtiainen, H., Öhman, M.C., 2014. Ecosystem services in the Baltic Sea: valuation of 984 marine and coastal ecosystem services in the Baltic Sea. Tema Nord 2014:563. Nordic 985 Council of Ministers, Copenhagen, 74 pp.

986 Airoldi, L., Beck, M.W., 2007. Loss, status and trends for coastal marine habitats of 987 Europe. Oceanography and Marine Biology: an Annual Review 45, 345-405.

988 Altartouri, A., Nurminen, L., Jolma, A., 2014. Modeling the role of the close-range effect 989 and environmental variables in the occurrence and spread of Phragmites australis in 990 four sites on the Finnish coast of the Gulf of Finland and the Archipelago Sea. Ecology 991 and Evolution 4, 987-1005.

992 Andersen, J.H., Kallenbach, E., 2016. A literature study of human activities and 993 pressures as well as ecosystem component layers available for Marine Spatial Planning 994 and mapping of cumulative impacts in Swedish marine waters. NIVA Denmark Water 995 Research 6997-2016. 36 pp. 
Andersen, J.H., Halpern, B.S., Korpinen, S., Murray, C., Reker, J., 2015. Baltic Sea

997

998

999

1000

1001

1002

1003

1004

1005

1006

1007

1008

1009

1010

1011

1012

1013

1014

1015

1016

1017

1018

1019

1020

biodiversity status vs. cumulative human pressures. Estuarine, Coastal and Shelf Science 161, 88-92.

Anon., 1992, Council Directive 92/43/EEC of 21 May 1992 on the conservation of natural habitats and of wild fauna and flora. Official Journal of the European Union 206, 7-50.

Anon., 2000. Directive 2000/60/EC of the European Parliament and of the council of 23 October 2000 establishing a framework for Community action in the field of water policy. Official Journal of the European Union L327, 1-72.

Anon., 2008. Directive 2008/56/EC of the European Parliament and of the Council of 17 June 2008 establishing a framework for community action in the field of marine environmental policy (Marine Strategy Framework Directive). Official Journal of the European Communities L 164/19.

Anon., 2013. Regulation (EU) No 1380/2013 of the European parliament and of the council of 11 December 2013 on the Common Fisheries Policy, amending Council Regulations (EC) No 1954/2003 and (EC) No 1224/2009 and repealing Council Regulations (EC) No 2371/2002 and (EC) No 639/2004 and Council Decision 2004/585/EC.

Anon., 2014. Directive 2014/89/EU of the European Parliament and of the Council of 23 July 2014 establishing a framework for maritime spatial planning. Official Journal of the European Union L 257/135.

Armstrong, C.W., Falk-Petersen, J., 2008. Habitat-fisheries interactions: a missing link? ICES Journal of Marine Science 65, 817-821.

Aro, E., 1989, A review of fish migration patterns in the Baltic. Rapports et Procesverbaux des Réunions. Conseil International pour l'Éxploration de la Mer 190, 72-96. 
1021

1022

1023

1024

1025

1026

1027

1028

1029

1030

1031

1032

1033

1034

1035

1036

1037

1038

1039

1040

1041

1042

1043

1044

Azour, F., van Deurs, M., Behrens, J., Carl, H., Hüssy, K., Greisen, K., Ebert, R., Møller, P.R., 2015. Invasion rate and population characteristics of the round goby Neogobius melanostomus: Effects of density and invasion history. Aquatic Biology 24, 41-52.

BACC Author Team, 2008. Assessment of climate change for the Baltic Sea basin. Springer Science \& Business Media.

Barton, D.R., Johnson, R.A., Campbell, L., Petruniak, J., Patterson, M., 2005. Effects of round gobies (Neogobius melanostomus) on dressenid mussels and other invertebrates in eastern Lake Erie, 2002-2004. Journal of Great Lakes Research 31, 252-261.

Beck, M.W., Heck, K.L., Able, K.W., Childers, D.L., Eggleston, D.B., Gillanders, B.M., Halpern, B., Hays, C.G., Hoshino, K., Minello, T, Orth, R.J., Sheridan, P.F., Weinstein, M.P., 2001. The identification, conservation, and management of estuarine and marine nurseries for fish and invertebrates. Bioscience 51, 633-641.

Benaka, L.R. (Ed.), 1999. Fish habitat: Essential fish habitat and rehabilitation. American Fisheries Society Symposium 22, Bethesda, MD.

Bergström, L., Heikinheimo, O., Svirgsden, R., Kruze, E., Ložys, L., Lappalainen, A., Saks, L., Minde, A., Dainys, J., Jakubavičiūtė, E., Ådjers, K., Olsson, J., 2016a. Long term changes in the status of coastal fish in the Baltic Sea. Estuarine, Coastal and Shelf Science 169, 7484.

Bergström, L., Bergström, U., Olsson, J., Carstensen, J. 2016b. Coastal fish indicators response to natural and anthropogenic drivers-variability at temporal and different spatial scales. Estuarine, Coastal and Shelf Science 183, 62-72.

Bergström, L., Karlsson, M., Bergström, U., Pihl, L., Kraufvelin, P., 2016c. Distribution of mesopredatory fish determined by habitat variables in a predator-depleted coastal system. Marine Biology 163, 201. 
Bergström, U., Sundblad, G., Downie, A.-L., Snickars, M., Boström, C., Lindegarth, M.,

2013. Evaluating eutrophication management scenarios in the Baltic Sea using species

1047

1048

1049

1050

1051

1052

1053

1054

1055

1056

1057

1058

1059

1060

1061

1062

1063

1064

1065

1066

1067

1068

1069 distribution modelling. Journal of Applied Ecology 50, 680-690.

Bergström, U., Olsson, J., Casini, M., Eriksson, B. K., Fredriksson, R., Wennhage, H., Appelberg, M., 2015. Stickleback increase in the Baltic Sea - A thorny issue for coastal predatory fish. Estuarine, Coastal and Shelf Science 163, 134-142.

Blaber, S.J.M., Blaber, T.G., 1980. Factors affecting the distribution of juvenile estuarine and inshore fish. Journal of Fish Biology 17, 143-162.

Bonsdorff, E., Pearson, T.H., 1999. Variation in the sublittoral macrozoobenthos of the Baltic Sea along environmental gradients: A functional-group approach. Australian Journal of Ecology 24, 312-326.

Bonsdorff, E., Blomqvist, E.M., Mattila, J., Norkko, A., 1997. Coastal eutrophication: causes, consequences and perspectives in the archipelago areas of the northern Baltic Sea. Estuarine, Coastal Shelf Science 44, 63-72.

Borja, A., 2014. Grand challenges in marine ecosystems ecology. Front Mar Sci 1:1.

Borja, A., Elliott, M., Andersen, J.H., Berg, T., Carstensen, J., Halpern, B.S., Heiskanen, A.S., Korpinen, S., Lowndes, J.S.S., Martin, G., Rodriguez-Ezpeleta, N., 2016. Overview of Integrative Assessment of Marine Systems: The Ecosystem Approach in Practice. Frontiers in Marine Science 3, 20.

Boström, C., Bonsdorff, E., Kangas, P., Norkko, A., 2002. Long-term changes of a brackish-water eelgrass (Zostera marina L.) community indicate effects of coastal eutrophication. Estuarine, Coastal and Shelf Science 55, 795-804.

Bouma, T.J., van Belzen, J., Balke, T., Zhu, Z., Airoldi, L., Blight, A.J., Davies, A.J., Galvan, C., Hawkins, S.J., Hoggart, S.P.G., Lara, J.L., Losada, I.J., Maza, M., Ondiviela, B., Skov, M.W., Strain, E.M., Thompson, R.C., Yang, S., Zanuttigh, B., Zhang, L., Herman, P.M.J., 2014. 
1070

1071

1072

1073

1074

1075

1076

1077

1078

1079

1080

1081

1082

1083

1084

1085

1086

1087

1088

1089

1090 1091307.

1092

1093

Identifying knowledge gaps hampering application of intertidal habitats in coastal protection: Opportunities \& steps to take. Coastal Engineering 87, 147-157.

Brown, A.C., McLachlan, A., 2002. Sandy shore ecosystems and the threats facing them: some predictions for the year 2025. Environmental Conservation 29, 62-77.

Bučas, M., Bergström, U., Downie, A.L., Sundblad, G., Gullström, M., von Numers, M., Šiaulys, A., Lindegarth, M., 2013. Empirical modelling of benthic species distribution, abundance, and diversity in the Baltic Sea: evaluating the scope for predictive mapping using different modelling approaches. ICES Journal of Marine Science 70, 1233-1243.

Byström, P., Bergström, U., Hjälten, A., Ståhl, S., Jonsson, D., Olsson, J., 2015. Declining coastal piscivore populations in the Baltic Sea: Where and when do sticklebacks matter? Ambio 44, 462-471.

Cardinale, M., Arrhenius, F., 2000. The influence of stock structure and environmental conditions on the recruitment process of Baltic cod estimated using a generalized additive model. Canadian Journal of Fisheries and Aquatic Sciences 57, 2402-2409.

Carl, J., Sparrevohn, C., Nicolajsen, N., Støttrup, J.G. 2008. Substratum selection by juvenile flounder Platichthys flesus (L.): effect of ephemeral filamentous macroalgae. J. Fish Biology 72, 2570-2578.

Carr, M.H., 1994. Effects of macroalgal dynamics on recruitment of a temperate reef fish. Ecology 75, 1320-1333.

Cattrijsse, A., Hampel, H., 2006. European intertidal marshes: a review of their habitat functioning and value for aquatic organisms. Marine Ecology Progress Series 324, 293-

Chapman, P.M., 2017. Assessing and managing stressors in a changing marine environment. Marine Pollution Bulletin 124, 587-590. 
Ciszewski, P., Kruk-Dowgiallo, L., Zmudzinski, L., 1992. Deterioration of the Puck Bay

1095

1096

1097

1098

1099

1100

1101

1102

1103

1104

1105

1106

1107

1108

1109

1110

1111

1112

1113

1114

1115

1116 1117 and biotechnical approaches to its reclamation. In: Bjørnestad, E., L. Hagerman, K. Jensen (Eds.), Proc. 12th Baltic Marine Biologists symp. Olsen \& Olsen, Fredensborg, pp. 43-46. Collie, J.S., Adamowicz, W.L., Beck, M.W., Craig, B., Essington, T.E., Fluharty, D., Rice, J., Sanchirico, J.N., 2013. Marine spatial planning in practice. Estuarine Coastal and Shelf Science 117, 1-11.

Conley, D.J., Björck, S., Bonsdorff, E., Carstensen, J., Destouni, G., Gustafsson, B. G., Hietanen, S., Kortekaas, M., Kuosa, H., Meier, H.E.M., Müller-Karulis, B., Nordberg, K., Norkko, A., Nürnberg, G., Pitkänen, H., Rabalais, N., Rosenberg, R., Savchuk, O.P., Slomp, C.P., Voss, M., Wulff, F., Zillén, L., 2009. Hypoxia-related processes in the Baltic Sea. Environmental Science and Technology 43, 3412-3420.

Crain, C.M., Kroeker, K., Halpern, B.S., 2008. Interactive and cumulative effects of multiple human stressors in marine systems. Ecology Letters 11, 1304-1315.

Dafforn, K.A., Mayer-Pinto, M., Morris, R.L., Waltham, N.J., 2015. Application of management tools to integrate ecological principles with the design of marine infrastructure. Journal of Environmental Management 158, 61-73.

Dahl, K., Stenberg, C., Lundsteen, S., Støttrup, J., Dolmer, P., Tendal, O.S., 2008. Ecology of Læsø Trindel - A reef impacted by extraction of boulders. Danish Forest and Nature Agency, $54 \mathrm{pp}$.

Díaz, E.R., Erlandsson, J., Westerbom, M., Kraufvelin, P., 2015. Depth-related spatial patterns of sublittoral blue mussel beds and their associated macrofauna diversity revealed by geostatistical analyses. Marine Ecology Progress Series 540, 121-134.

Duarte, C.M., 2014. Global change and the future ocean: a grand challenge for marine sciences. Frontiers in Marine Science, 1, 63. 
Eddy, T.D., Lotze, H.K., Fulton, E.A., Coll, M., Ainsworth, C.H., de Araújo, J.N., Bulman, C.M., Bundy, A., Christensen, V., Field, J.C., Gribble, N.A., Hasan, M., Mackinson, S., Townsend, H., 2017. Ecosystem effects of invertebrate fisheries. Fish and Fisheries, 18:

$112140-53$.

Elith, J., Leathwick, J.R., 2009. Species distribution models: ecological explanation and prediction across space and time. Annual Review of Ecology, Evolution and Systematics 40, 677-697.

Elliott, M., 2004. Marine habitats: loss and gain, mitigation and compensation. Marine Pollution Bulletin 49, 671-674.

Elliott, M., 2010. Marine science and management means tackling exogenic

1128 unmanaged pressures and endogenic managed pressures - a numbered guide. Marine 1129 Pollution Bulletin 62, 651-655.

1130 Elliott, M., Mander, L., Mazik, K., Simenstad, C., Valesini, F., Whitfield, A., Wolanski, E.,

1131 2016. Ecoengineering with Ecohydrology: Successes and failures in estuarine 1132 restoration. Estuarine Coastal and Shelf Science 176, 12-35.

1133 Elliott, S.A.M., Milligan, R.J., Heath, M.R., Turrell, W.R., Bailey, D.B., 2016. Disentangling

1134 habitat concepts for demersal marine fish management. Oceanography and Marine 1135 Biology: An Annual Review 54, 173-191.

1136 Engelsen, A., Hulth, S., Pihl, L., Sundbäck, K., 2008. Benthic trophic status and nutrient 1137 fluxes in shallow-water sediments. Estuarine, Coastal and Shelf Science 78, 783-795.

1138 Engstedt, O., Stenroth, P., Larsson, P., Ljunggren, L., Elfman, M., 2010. Assessment of 1139 natal origin of pike (Esox lucius) in the Baltic Sea using Sr:Ca in otoliths. Environmental 1140 Biology of Fishes 89, 547-555. 
Engström-Öst, J., Mattila, J., 2008. Foraging, growth and habitat choice in turbid water:

1142

1143

1144

1145

1146

1147

1148

1149

1150

1151

1152

1153

1154

1155

1156

1157

1158

1159

1160

1161

1162

1163

1164

an experimental study with fish larvae in the Baltic Sea. Marine Ecology Progress Series $359,275-281$.

Engström-Öst, J., Immonen, E., Candolin, U., Mattila, J., 2007. The indirect effects of eutrophication on habitat choice and survival of fish larvae in the Baltic Sea. Marine Biology 151, 393-400.

Eriksson, B.K., Johansson, G., Snoeijs, P., 1998. Long-term changes in the sublittoral zonation of brown algae in the southern Bothnian Sea. European Journal of Phycology $33,241-249$.

Eriksson, B.K., Sandström, A., Isæus, M., Schreiber, H., Karås, P., 2004. Effects of boating activities on aquatic vegetation in the Stockholm archipelago, Baltic Sea. Estuarine, Coastal and Shelf Science 61, 339-349.

Eriksson, B.K., Ljunggren, L., Sandström, A., Johansson, G., Mattila, J., Rubach, A., Råberg, S., Snickars, M., 2009. Declines in predatory fish promote bloom-forming macroalgae. Ecological Applications 19, 1975-1988.

Eriksson B.K., Sieben, K., Eklöf, J., Ljunggren, L., Olsson, J., Casini, M., Bergström, U., 2011. Effects of altered offshore food webs on coastal ecosystems emphasize the need for cross-ecosystem management. Ambio 40, 786-797.

Fabi, G., Spagnolo, A., Bellan-Santini, D., Charbonnel, E., Cicek, B.A., Goutayer Garcia, J.J., Jensen, A.C., Kallianiotis, A., dos Santos, M.N., 2011. Overview on artificial reefs in Europe. Brazilian Journal of Oceanography 59, 155-166.

Florin, A.-B., Sundblad, G., Bergström, U., 2009. Characterisation of juvenile flatfish habitats in the Baltic Sea. Estuarine, Coastal and Shelf Science 82, 294-300.

Fluharty, D., 2000. Habitat protection, ecological issues, and implementation of the Sustainable Fisheries Act. Ecological Applications 10, 325-337. 
Fodrie, F.J., Levin, L.A., 2008. Linking juvenile habitat utilization to population dynamics of California halibut. Limnology and Oceanography 53, 799-812.

Fodrie, F.J., Levin, L.A., Lucas, A.J., 2009. Use of population fitness to evaluate the nursery function of juvenile habitats. Marine Ecology Progress Series 385, 39-49.

1170 Fredriksson, R., Bergström, U., Olsson, J., 2013. Riktlinjer för uppföljning av

1171 fiskevårdsåtgärder i kustmynnande våtmarker med fokus på gädda. Aqua Reports

1172 2013:7. Sveriges Lantbruksuniversitet, Öregrund, 52 pp. (In Swedish)

1173 Gagnon, K., Boström, C., 2016. Habitat expansion of the Harris mud crab

1174 Rhithropanopeus harrisii (Gould, 1841) in the northern Baltic Sea: potential

1175 consequences for the eelgrass food web. BioInvasions Records 5, 101-106.

1176 Gerbersdorf, S.U., Meyercordt, J., Meyer-Reil, L.A., 2005. Microphytobenthic primary

1177 production in the Bodden estuaries, southern Baltic Sea, at two study sites differing in 1178 trophic status. Aquatic Microbial Ecology 41, 181-198.

1179 Gibson, R.N., 1994. Impact of habitat quality and quantity on the recruitment of 1180 juvenile flatfishes. Netherlands Journal of Sea Research 32, 191-206.

1181 Gillanders, B., Able, K., Brown, J., Eggleston, D., Sheridan, P., 2003. Evidence of 1182 connectivity between juvenile and adult habitats for mobile marine fauna: an important 1183 component of nurseries. Marine Ecology Progress Series 247, 281-295.

1184 Graiff, A., Liesner, D., Karsten, U., Bartsch, I., 2015. Temperature tolerance of western 1185 Baltic Sea Fucus vesiculosus - growth, photosynthesis and survival. Journal of 1186 Experimental Marine Biology and Ecology 471, 8-16.

1187 Graiff, A., Dankworth, M., Wahl, M., Karsten, U., Bartsch, I., 2017. Seasonal variations of

1188 Fucus vesiculosus fertility under ocean acidification and warming in the western Baltic 1189 Sea. Botanica Marina 60, 239-255. 
de Groot, R., Brander, L., van der Ploeg, S., Costanza, R., Bernard, F., Braat, L., Christie,

1191 M., Crossman, N., Ghermandi, A., Hein, L., Hussain, S., Kumar, P., McVittie, A., Portela, R.,

1192 Rodriguez, L.C., ten Brink, P., van Beukering, P., 2012. Global estimates of the value of

1193 ecosystems and their services in monetary units. Ecosystem Services 1, 50-61.

1194 Halpern, B.S., Gaines, S.D., Warner, R.R., 2005. Habitat size, recruitment, and longevity 1195 as factors limiting populations size in stage-structured species. American Naturalist 165, $119682-94$.

1197 Halpern, B.S., Walbridge, S., Selkoe, K.A., Kappel, C.V., Micheli, F., D'Agrosa, C., Bruno, 1198 J.F., Casey, K.S., Ebert, C., Fox, H.E., Fujita, R., Heinemann, D., Lenihan, H.S., Madin, E.M.P., 1199 Perry, M.T., Selig, E.R., Spalding, M., Steneck, R., Watson, R., 2008. A global map of human 1200 impact on marine ecosystems. Science 319, 948-952.

1201 Hansen, J.P., Snickars, M., 2014. Applying macrophyte community indicators to assess anthropogenic pressures on shallow soft bottoms. Hydrobiologia 738, 171-189.

Härmä, M., Lappalainen, A., Urho, L., 2008. Reproduction areas of roach (Rutilus rutilus) in the northern Baltic Sea: potential effects of climate change. Canadian Journal of Fisheries and Aquatic Sciences 65, 2678-2688.

Havenhand, J.N., 2012. How will ocean acidification affect Baltic Sea ecosystems? An assessment of plausible impacts on key functional groups. Ambio 41, 637-644.

1208 Heikinheimo, O., Pekcan-Hekim, Z., Raitaniemi, J., 2014. Spawning stock-recruitment 1209 relationship in pikeperch Sander lucioperca (L.) in the Baltic Sea, with temperature as an 1210 environmental effect. Fisheries Research 155, 1-9.

1211 HELCOM, 2007. HELCOM Baltic Sea Action Plan. Helsinki Commission.

1212 HELCOM, 2010. Towards a tool for quantifying the anthropogenic pressures and 1213 potential impacts in the Baltic Sea marine environment. A background document on the 1214 method, data preparation and testing of the Baltic Sea Pressure and Impact Indices. 
1215 Baltic Sea Environment Proceedings 125. Available at: http://www.helcom.fi/helcomat-work/publications/baltic-sea-environment-proceedings/ HELCOM, 2012. Indicator based assessment of coastal fish community status in the Baltic Sea 2005-2009. Baltic Sea Environment Proceeding No. 131.

HELCOM, 2013. Climate change in the Baltic Sea Area: HELCOM thematic assessment in 2013. Baltic Sea Environment Proceeding No. 137.

HELCOM, 2017, First version of the 'State of the Baltic Sea' report - June 2017 - to be updated in 2018. Available at: $\underline{\text { http://stateofthebalticsea.helcom.fi }}$

Helle, I., Jolma, A., Venesjärvi, R., 2016. Species and habitats in danger: estimating the relative risk posed by oil spills in the northern Baltic Sea. Ecosphere 7, e01344

Hemminga, M.A., Duarte, C.M., 2000. Seagrass Ecology. Cambridge University Press, Cambridge, 298 pp.

Hinrichsen, H.H., von Dewitz, B., Lehmann, A., Bergström, U., Hüssy, K. (2017). Spatiotemporal dynamics of cod nursery areas in the Baltic Sea. Progress in Oceanography $155,28-40$.

Holmlund, C.M., Hammer, M., 1999. Ecosystem services generated by fish populations. Ecological Economics 29, 253-268.

Hopkins, C.C.E., 2003. The dangers of bottom trawling in the Baltic Sea. A report for Coalition Clean Baltic. Aquamarine advisers.

Hopkins, T.S., Bailly, D., Støttrup, J.G., 2011. A Systems Approach Framework for Coastal Zones. Ecology and Society 16, 25.

Idestam-Almquist, J., 2000. Dynamics of submersed aquatic vegetation on shallow soft bottoms in the Baltic Sea. Journal of Vegetation Science 11, 425-432.

Iles, T.C., Beverton, R.J.H., 2000. The concentration hypothesis: the statistical evidence. ICES Journal of Marine Science 57, 216-227. 
Islam, M.S., Tanaka, M., 2004. Impacts of pollution on coastal and marine ecosystems

1241 including coastal and marine fisheries and approach for management: a review and

1242

1243

1244

1245

1246

1247

1248

1249

1250

1251

1252

1253

1254

1255

1256

1257

1258

1259

1260

1261

1262

1263 synthesis. Marine Pollution Bulletin 48, 624-649.

Ivarsson, M., Magnussen, K., Heiskanen, A.-S., Navrud, S., Viitasalo, M., 2017. Ecosystem services in MSP: Ecosystem services approach as a common Nordic understanding for MSP. TemaNord 2017:536. Nordic Council of Ministers. http://dx.doi.org/10.6027/TN2017-56

Jackson, E.L., Rowden, A.A., Attrill, M.J., Bossey, S.J., Jones, M.B., 2001. The importance of seagrass beds as a habitat for fishery species. Oceanography and Marine Biology: an Annual Review 39, 269-304.

Jackson, J.B.C., Kirby, M.X., Berger, W.H., Bjorndal, K.A., Botsford, L.W., Bourque, B.J., Bradbury, R., Cooke, R., Erlandson, J., Estes, J.A., Hughes, T.P., Kidwell, S., Lange, C.B., Lenihan, H.S., Pandolfi, J.M., Peterson, C.H., Steneck, R.S., Tegner, M.J., Warner, R., 2001. Historical overfishing and the recent collapse of coastal ecosystems. Science 293, 629638.

Järv, L., Kotta, J., Kotta, I., Raid, T., 2011. Linking the structure of benthic invertebrate communities and the diet of native and invasive fish species in a brackish water ecosystem. Annales Zoologici Fennici 49, 129-141.

Jokinen, H., Wennhage, H., Lappalainen, A., Ådjers, K., Rask, M., Norkko, A., 2015. Decline of flounder (Platichthys flesus (L.)) at the margin of the species' distribution range. Journal of Sea Research 105, 1-9.

Jokinen, H., Wennhage, H., Ollus, V., Aro, E., Norkko, A., 2016. Juvenile flatfish in the northern Baltic Sea - long-term decline and potential links to habitat characteristics. Journal of Sea Research 107, 67-75. 
Jormalainen, V., Gagnon, K., Sjöroos, J., Rothäusler, E., 2016. The invasive mud crab enforces a major shift in a rocky littoral invertebrate community of the Baltic Sea. Biological Invasions 18, 1409-1419.

Kallasvuo, M., Salonen, M., Lappalainen, A., 2009. Does the zooplankton prey availability limit the larval habitats of pike in the Baltic Sea? Estuarine, Coastal and Shelf Science 86, 148-156.

Kallasvuo, M., Vanhatalo, J., Veneranta, L., 2017. Modeling the spatial distribution of larval fish abundance provides essential information for management. Canadian Journal of Fisheries and Aquatic Sciences 74, 636-649.

Kappel, C.V., 2005. Losing pieces of the puzzle: threats to marine, estuarine, and diadromous species. Frontiers in Ecology and the Environment 3, 275-282.

Karås, P., 1996. Basic abiotic conditions for production of perch (Perca fluviatilis L.) young-of-the-year in the Gulf of Bothnia. Annales Zoologici Fennici 33, 371-381.

Karås, P., Hudd, R., 1993. Reproduction areas of fish in the northern Quark (Gulf of Bothnia). Aqua Fennica 23, 39-49.

Karlson, A.M.L., Almqvist, G., Skora, K.E., Appelberg, M., 2007. Indications of competition between non-indigenous round goby and native flounder in the Baltic Sea. ICES Journal of Marine Science 64, 479-486.

Karlson, K., Rosenberg, R., Bonsdorff, E., 2002. Temporal and spatial large-scale effects of eutrophication and oxygen deficiency on benthic fauna in Scandinavian and Baltic waters - a review. Oceanography Marne Biology: an Annual Review 40, 427-489.

Katsanevakis, S., Wallentinus, I., Zenetos, A., Leppäkoski, E., Çinar, M.E., Oztürk, B., Grabowski, M., Golani, D., Cardoso, A.C., 2014. Impacts of invasive alien marine species on ecosystem services and biodiversity: a pan-European review. Aquatic Invasions 9, $391-423$. 
Kautsky, N., Kautsky, H., Kautsky, U., Waern, M., 1986. Decreased depth penetration of Fucus vesiculosus (L.) since the 1940's indicates eutrophication of the Baltic Sea. Marine

1291 Ecology Progress Series 28, 1-8.

1292 Kenny, A.J., Skjoldal, H.R., Engelhard, G.H., Kershaw, P.J., Reid, J.B., 2009. An integrated 1293 approach for assessing the relative significance of human pressures and environmental 1294 forcing on the status of Large Marine Ecosystems. Progress in Oceanography 81, 1321295148.

1296 Kneib, K.T., Wagner, S.L., 1994. Nekton use of vegetated marsh habitats at different 1297 stages of tidal inundation. Marine Ecology Progress Series 106, 227-238.

1298 Kornis, M.S., Mercado-Silva, N., Vander Zanden, M.J., 2012. Twenty years of invasion: a 1299 review of round goby Neogobius melanostomus biology, spread and ecological 1300 implications. Journal of Fish Biology 80, 235-285.

1301 Korpinen, S., Honkanen, T., Vesakoski, O., Hemmi, A., Koivikko, R., Loponen, J., 1302 Jormalainen, V., 2007. Macroalgal communities face the challenge of changing biotic 1303 interactions: review with focus on the Baltic Sea. Ambio 36, 203-211.

1304 Korpinen, S., Meski, L., Andersen, J.H., Laamanen, M., 2012. Human pressures and their 1305 potential impact on the Baltic Sea ecosystem. Ecological Indicators 15, 105-114.

1306 Kotta, J., Nurkse, K., Puntila, R., Ojaveer, H., 2016. Shipping and natural environmental 1307 conditions determine the distribution of the invasive non-indigenous round goby 1308 Neogobius melanostomus in a regional sea. Estuarine, Coastal and Shelf Science 169, 15130924.

1310 Kraufvelin, P., 2007. Responses to nutrient enrichment, wave action and disturbance 1311 in rocky shore communities. Aquatic Botany 87, 262-274.

1312 Kraufvelin, P., Díaz, E.R., 2015. Sediment macrofauna communities at a small mussel 1313 farm in the northern Baltic proper. Boreal Environment Research 20, 378-390. 
Kraufvelin, P., Ruuskanen, A.T., Nappu, N., Kiirikki, M., 2007. Winter colonisation and succession of filamentous algae on artificial substrates and possible relationships to

Fucus vesiculosus settlement in early summer. Estuarine, Coastal and Shelf Science 72, 665-674.

1318 Kraufvelin, P., Lindholm, A., Pedersen, M.F., Kirkerud, L.A., Bonsdorff, E., 2010. 1319 Biomass, diversity and production of rocky shore macroalgae at two nutrient 1320 enrichment and wave action levels. Marine Biology 157, 29-47.

1321 Kraufvelin, P., Ruuskanen, A.T., Bäck, S., Russell, G., 2012. Increased seawater 1322 temperature and light during early springs accelerate receptacle growth of Fucus 1323 vesiculosus in the northern Baltic proper. Marine Biology 159, 1795-1807.

1324 Kraufvelin, P., Pekcan-Hekim, Z., Bergström, U., Florin, A.-B., Lehikoinen, A., Mattila, J., 1325 Olsson, J., 2016. Essential fish habitats (EFH): Conclusions from a workshop on the 1326 importance, mapping, monitoring, threats and conservation of coastal EFH in the Baltic 1327 Sea. TemaNord 2016, 539.

1328 Lappalainen, A., Westerbom, M., Vesala, S., 2004. Blue mussels (Mytilus edulis) in the 1329 diet of roach (Rutilus rutilus) in outer archipelago areas of the western Gulf of Finland, 1330 Baltic Sea. Hydrobiologia 514, 87-92.

1331 Lappalainen, A., Westerbom, M., Heikinheimo, 0., 2005. Roach (Rutilus rutilus) as an 1332 important predator on blue mussel (Mytilus edulis) populations in a brackish water 1333 environment, the northern Baltic Sea. Marine Biology 147, 323-330.

1334 Lappalainen, A., Härma, M., Kuningas, S., Urho, L., 2008. Reproduction of pike (Esox 1335 lucius) in reed belt shores of the SW coast of Finland, Baltic Sea: a new survey approach. 1336 Boreal Environment Research 13, 370-380.

1337 Laurila-Pant, M., Lehikoinen, A., Uusitalo, L., Venesjärvi, R., 2015. How to value 1338 biodiversity in environmental management? Ecological Indicators 55, 1-11. 
Leathwick, J., Moilanen, A., Francis, M., Elith, J., Taylor, P., Julian, K., Hastie, T., Duffy, C., 2008. Novel methods for the design and evaluation of marine protected areas in offshore waters. Conservation Letters 1, 91-102.

Leppäkoski, E., Bonsdorff, E., 1989. Ecosystem variability and gradients. Examples from the Baltic Sea as a background for hazard assessment. In: Landner, L. (Ed.), Chemicals in the Aquatic Environment, Springer Berlin Heidelberg, pp. 6-58.

$$
\text { Leppäkoski, E., Gollasch, S., Gruszka, P., Ojaveer, H., Olenin, S., Panov, V., 2002. The }
$$
Baltic a sea of invaders. Canadian Journal of Fisheries and Aquatic Sciences 59, 11751188.

Levin, P.S., Stunz, G.W., 2005. Habitat triage for exploited fishes: Can we identify essential “Essential Fish Habitat?” Estuarine, Coastal and Shelf Science 64, 70-78.

Liversage, K., Nurkse, K., Kotta, J., Järv, L., 2017. Environmental heterogeneity associated with European perch (Perca fluviatilis) predation on invasive round goby (Neogobius melanostomus). Marine Environmental Research 132, 132-139.

$$
\text { Ljunggren, L., 2002. Growth response of pikeperch larvae in relation to body size and }
$$
zooplankton abundance. Journal of Fish Biology 60, 405-414.

$$
\text { Ljunggren, L., Sandström A., Bergström U., Mattila J., Lappalainen A., Johansson G., }
$$
Sundblad G., Casini M., Kaljuste O., Eriksson, B.K., 2010. Recruitment failure of coastal predatory fish in the Baltic Sea is related to an offshore system shift. ICES Journal of Marine Science 67, 1587-1595.

Lokko, K., Kotta, J., Orav-Kotta, H., Nurkse, K., Pärnoja, M., 2017. Introduction of a functionally novel consumer to a low diversity system: effects of the mud crab Rhithropanopeus harrisii on meiobenthos. Estuarine, Coastal and Shelf Science (in press). Long, R.D., Charles, A., Stephenson, R.L., 2015. Key principles of marine ecosystembased management. Marine Policy 57, 53-60. 
Lotze, H.K., 2004. Repetitive history of resource depletion and mismanagement: the need for a shift in perspective. Marine Ecology Progress Series 274, 269-303.

Lotze, H.K., Lenihan, H.S., Bourque, B.J., Bradbury, R.H, Cooke, R.G., Kay, M.C., Kidwell, S.M., Kirby, M.X., Peterson, C.H., Jackson, J.B.C., 2006. Depletion, degradation, and recovery potential of estuaries and coastal seas. Science 312, 1806-1809.

Lundberg, C., 2005. Eutrophication in the Baltic Sea: From area-specific biological effects to interdisciplinary consequences. PhD-thesis, Åbo Akademi University, 166 pp. MacKenzie, B.R., Hinrichsen, H.H., Plikshs, M., Wieland, K., Zezera, A.S., 2000. Quantifying environmental heterogeneity: estimating the size of habitat for successful cod egg development in the Baltic Sea. Marine Ecology Progress Series 193, 143-156.

MacKenzie, B.R., Gislason, H., Möllmann, C., Köster, F.W., 2007. Impact of 21st century climate change on the Baltic Sea fish community and fisheries. Global Change Biology, $13,1348-1367$.

Macura, B., Lönnstedt, O.M., Byström, P., Airoldi, L., Eriksson, B.K., Rudstam, L., Støttrup, J., 2016. What is the impact on fish recruitment of anthropogenic physical and structural habitat change in shallow nearshore areas in temperate systems? A systematic review protocol. Environmental Evidence 5, 10.

Mangel, M., Levin, P., Patil, A., 2006. Using life history and persistence criteria to prioritize habitats for management and conservation. Ecological Applications 16, 797806.

McCormick, S.D., Hansen, L.P., Quinn, T.P., Saunders, R.L., 1998. Movement, migration, and smolting of Atlantic salmon (Salmo salar). Canadian Journal of Fisheries and Aquatic Sciences 55, 77-92.

McLusky, D.S., Elliott, M., 2004. The Estuarine Ecosystem: Ecology, Threats and Management. New York: Oxford University Press. 224. 
Meriste, M., Kirsimäe, K., 2015. Development of the reed bed in Matsalu wetland, Estonia: responses to neotectonic land uplift, sea level changes and human influences.

1391 Estonian Journal of Earth Sciences 64, 159.

1392 Minns, C.K., Randall, R.G., Moore, J.E., Cairns, V.W., 1996. A model simulating the 1393 impact of habitat supply limits on northern pike, Esox lucius, in Hamilton Harbour, Lake 1394 Ontario. Canadian Journal of Fisheries and Aquatic Sciences 53, 20-34.

1395 Möllmann, C., Lindegren, M., Blenckner, T., Bergström, L., Casini, M., Diekmann, R., 1396 Flinkman, J., Müller-Karulis, B., Neuenfeldt, S., Schmidt, J.O., Tomczak, M., Voss, R., 1397 Gårdmark, A., 2014. Implementing ecosystem-based fisheries management: from single1398 species to integrated ecosystem assessment and advice for Baltic Sea fish stocks. ICES 1399 Journal of Marine Science 71, 1187-1197.

1400 Moore, C., Drazen, J.C., Radford, B.T., Kelley, C., Newman, S.J., 2016. Improving 1401 essential fish habitat designation to support sustainable ecosystem-based fisheries 1402 management. Marine Policy 69, 32-41.

1403 Mumby, P.J., Edwards, A.J., Arias-González, J.E., Lindeman, K.C., Blackwell, P.G., Gall, A., 1404 Gorczynska, M.I., Harborne, A.R., Pescod, C.L., Renken, H., Wabnitz, C.C.C., Llewellyn, G., 1405 2004. Mangroves enhance the biomass of coral reef fish communities in the Caribbean. 1406 Nature 427, 533-536.

1407 Newell, R.C., Seiderer, L.J., Hitchcock, D.R., 1998. The impact of dredging works in 1408 coastal waters: a review of the sensitivity to disturbance and subsequent recovery of 1409 biological resources on the sea bed. Oceanography and Marine Biology: an Annual $1410 \quad$ Review 36, 127-178.

1411 Nilsson, J., Engstedt, O., Larsson, P., 2014. Wetlands for northern pike (Esox lucius L.) 1412 recruitment in the Baltic Sea. Hydrobiologia 721, 145-154. 
1413

1414

1415

1416

1417

1418

1419

1420

1421

1422

1434 decadal changes in coastal zoobenthos communities in two Baltic Sea areas. PLoS One 1435 8:e64767.

1436 Olsson, J., Tomczak, M.T., Ojaveer, H., Gårdmark, A., Põllumäe, A., Müller-Karulis, B., 1437 Ustups, D., Dinesen, G.E., Peltonen, H., Putnis, I., Szymanek, L., Simm, M., Heikinheimo, O., 
Gasyukov, P., Axe, P., Bergström, L., 2015. Temporal development of coastal ecosystems in the Baltic Sea over the past two decades. ICES Journal of Marine Science 72, 25392548.

Orio, A., Bergström, U., Casini, M., Erlandsson, M., Eschbaum, R., Hüssy, K., Lehmann, A., Ložys L., Ustups, D., Florin, A-B., 2017. Characterizing and predicting the distribution of Baltic Sea flounder (Platichthys flesus) during the spawning season. Journal of Sea Research 126, 46-55.

Orth, R.J., Carruthers, T.J., Dennison, W.C., Duarte, C.M., Fourqurean, J.W., Heck, K.L., Hughes, A.R., Kendrick, G.A., Kenworthy, W.J., Olyarnik, S., Short, F.T., Waycott, M., Williams, S.L., 2006. A global crisis for seagrass ecosystems. Bioscience 56, 987-996.

Österblom, H., Hansson, S., Larsson, U., Hjerne, O., Wulff, F., Elmgren, R., Folke, C., 2007. Human-induced trophic cascades and ecological regime shifts in the Baltic Sea. Ecosystems 10, 877-889.

Östman, Ö., Eklöf, J., Eriksson, B.K., Olsson, J., Moksnes, P.-O., Bergström, U., 2016. Topdown control as important as nutrient enrichment for eutrophication effects in North Atlantic coastal ecosystems. Journal of Applied Ecology 53, 1138-1147.

Östman, Ö., Lingman, A., Bergström, L., Olsson, J., 2017. Temporal development and spatial scale of coastal fish indicators in reference ecosystems: hydroclimate and anthropogenic drivers. Journal of Applied Ecology 54, 557-566.

Paerl, H.W., Otten, T.G., 2013. Harmful cyanobacterial blooms: causes, consequences, and controls. Microbial Ecology 65, 995-1010.

Persson, L., Diehl, S., Johansson, L., Andersson, G., Hamrin, S.F., 1991. Shifts in fish communities along the productivity gradient of temperate lakes - patterns and the importance of size-structured interactions. Journal of Fish Biology 38, 281-293. 
1462

1463

1464

1465

1466

1467

1468

1469

1470

1471

1472

1473

1474

1475

1476

1477

1478

1479

1480

1481

1482

1483

1484

1485

Pihl, L., Wennhage, H., 2002. Structure and diversity of fish assemblages on rocky and soft bottom shores on the Swedish west coast. Journal of Fish Biology 61, 148-166.

Pihl, L., Wennhage, H., Nilsson S., 1994. Fish assemblage structure in relation to macrophytes and filamentous epiphytes in shallow non-tidal rocky- and soft-bottom habitats. Environmental Biology of Fishes 39, 271-288.

Pikitch, E.K., Santora, C., Babcock, E.A., Bakun, A., Bonfil, R., Conover, D.O., Dayton, P.K., Doukakis, P., Fluharty, D., Heneman, B., Houde, E.D., Link, J., Livingston, P.A., Mangel, M., McAllister, M.K., Pope, J., Sainsbury, K.J., 2004. Ecosystem-based fishery management. Science 305, 346-347.

Pikitch, E.K., Rountos, K.J., Essington, T.E., Santora, C., Pauly, D., Watson, R., Sumaila, U.R., Boersma, P.D., Boyd, I.L., Conover, D.O., Cury, P., Heppell, S.S., Houdes, E.D., Mangel, M., Plagányi, E., Sainsbury, K., Steneck, R.,S., Geers, T.M., Gownaris, Munch, S.B., 2014. The global contribution of forage fish to marine fisheries and ecosystems. Fish and Fisheries $15,43-64$.

Pitkänen, H., Peuraniemi, M., Westerbom, M., Kilpi, M., von Numers, M., 2013. Longterm changes in distribution and frequency of aquatic vascular plants and charophytes in an estuary in the Baltic Sea. Annales Botanici Fennici 50, 1-54.

Pittman, S.J., Brown, K.A., 2011. Multi-scale approach for predicting fish species distributions across coral reef seascapes. PLoS One 6, e20583.

Plinski, M., Florczyk, I., 1984. Changes in the phytobenthos resulting from the eutrophication of the Puck Bay. Limnologica 15, 325-327.

Pommer, C.D., Olesen, M., Hansen, J.L., 2016. Impact and distribution of bottom trawl fishing on mud-bottom communities in the Kattegat. Marine Ecology Progress Series 548, 47-60. 
1486

1487

1488

1489

1490

1491

1492

1493

1494

1495

1496

1497

1498

1499

1500

1501

1502

1503

1504

1505

1506

1507

1508

1509

1510

Powers, S.P., Peterson, C.H., Christian, R.R., Sullivan, E., Powers, M.J., Bishop, M.J., Buzzelli, C.P., 2005. Effects of eutrophication on bottom habitat and prey resources of demersal fishes. Marine Ecology Progress Series 302, 233-243.

Pulkkinen, H., Mäntyniemi, S., Kuikka, S., Levontin, P., 2011. More knowledge with the same amount of data: advantage of accounting for parameter correlations in hierarchical meta-analyses. Marine Ecology Progress Series 443, 29-37.

Råberg, S., Jönsson B.R., Björn, A., Granéli, E., Kautsky, L., 2005. Effects of Pilayella littoralis on Fucus vesiculosus recruitment. Implications for community composition. Marine Ecology Progress Series 289, 131-139.

Rahikainen, M., Helle, I., Haapasaari, P., Oinonen, S., Kuikka, S., Vanhatalo, J., Mäntyniemi, S., Hoviniemi, K.M., 2014. Toward integrative management advice of water quality, oil spills, and fishery in the Gulf of Finland: A Bayesian approach. Ambio 43, 115123.

Rajasilta, M., Eklund, J., Kääriä, J., Ranta-Aho, K., 1989. The deposition and mortality of the eggs of the Baltic herring Clupea harengus membras L., on different substrates in the south-west archipelago of Finland. Journal of Fish Biology 34, 417-427.

Rakauskas, V., Pūtys, Ž., Dainys, J., Lesutienè, J., Ložys, L., Arbačiauskas, K., 2013. Increasing population of the invader round goby, Neogobius melanostomus (Actinopterygii: Perciformes: Gobiidae), and its trophic role in the Curonian Lagoon, SE Baltic Sea. Acta Ichthyologica et Piscatoria 43, 95-108.

Rice, J.C., 2005. Understanding fish habitat ecology to achieve conservation. Journal of Fish Biology 67, 1-22.

Rijnsdorp, A.D., Van Beek, F.A., Flatman, S., Millner, R.M., Riley, J.D., Giret, M., De Clerck, R., 1992. Recruitment of sole stocks, Solea solea (L.), in the Northeast Atlantic. Netherlands Journal of Sea Research 29, 173-192. 
Rinne, H., Salovius-Laurén, S., Mattila, J., 2011. The occurrence and depth penetration

1512 of macroalgae along environmental gradients in the northern Baltic Sea. Estuarine,

1513 Coastal and Shelf Science 94, 182-191.

1514 Rohtla, M., 2015. Otolith sclerochronological studies on migrations, spawning habitat

1515 preferences and age of freshwater fishes inhabiting the Baltic Sea. Doctoral dissertation, 1516 University of Tartu, Estonia.

1517 Rohtla, M., Vetemaa, M., Urtson, K., Soesoo, A., 2012. Early life migration patterns of 1518 Baltic Sea pike Esox lucius. Journal of Fish Biology 80, 886-893.

1519 Rohtla, M., Vetemaa, M., Taal, I., Svirgsden, R., Urtson, K., Saks, L., Verliin, A., Kesler, M.,

1520 Saat, T., 2014. Life history of anadromous burbot (Lota lota, Linneaus) in the brackish 1521 Baltic Sea inferred from otolith microchemistry. Ecology of Freshwater Fish 23, 1411522148.

1523 Rohtla, M., Svirgsden, R., Taal, I., Saks, L., Eschbaum, R., Vetemaa, M., 2015. Life history 1524 characteristics of ide Leuciscus idus in the Eastern Baltic Sea. Fisheries Management and 1525 Ecology 22, 239-248.

1526 Rohtla, M., Svirgsden, R., Verliin, A., Rumvolt, K., Matetski, L., Hommik, K, Saks, L., 1527 Vetemaa, M., 2017. Developing novel means for unravelling population structure, 1528 provenance and migration patterns of European whitefish Coregonus lavaretus s.l. in the 1529 Baltic Sea. Fisheries Research 187, 47-57.

1530 Rönnbäck, P., Kautsky, N., Pihl, L., Troell, M., Söderqvist, T., Wennhage, H., 2007. 1531 Ecosystem goods and services from Swedish coastal habitats: identification, valuation, 1532 and implications of ecosystem shifts. Ambio 36, 534-544

1533 Rose, K.A., 2000. Why are quantitative relationships between environmental quality 1534 and fish populations so elusive? Ecological Applications 10, 367-385. 
1535 Rosenberg, A., Bigford, T.E., Leathery, S., Hill, R.L., Bickers, K., 2000. Ecosystem approaches to fishery management through essential fish habitat. Bulletin of Marine Science 66, 535-542.

Rosqvist, K., Mattila, J., Sandström, A., Snickars, M., Westerbom, M., 2010. Regime shifts in vegetation composition of Baltic Sea coastal lagoons. Aquatic Botany 93, 39-46. Sandström, A., Karås, P., 2002. Effects of eutrophication on young-of-the-year freshwater fish communities in coastal areas of the Baltic. Environmental Biology of 1542 Fishes 63, 89-101.

1543 Sandström, A., Eriksson, B.K., Karås, P., Isæus, M., Schreiber, H., 2005. Boating and 1544 navigation activities influence the recruitment of fish in a Baltic Sea archipelago area. 1545 Ambio 34, 125-130.

1546 Schmitt, R.J., Holbrook, S.J., 2000. Habitat-limited recruitment of coral reef damselfish. 1547 Ecology 81, 3479-3494.

1548 Seaman, W., 2007. Artificial habitats and the restoration of degraded marine 1549 ecosystems and fisheries. Hydrobiologia 580, 143-155.

1550 Seitz, R.D., Wennhage, H., Bergström, U., Lipcius, R.N., Ysebaert, T., 2014. Ecological 1551 value of coastal habitats for commercially and ecologically important species. ICES 1552 Journal of Marine Science 71, 648-665.

1553 Sheaves, M., Baker, R., Nagelkerken, I., Connolly, R.M., 2015. True value of estuarine 1554 and coastal nurseries fir Fish: Incorporating complexity and dynamics. Estuaries and 1555 Coasts 38, 401-414.

1556 Šiaulys, A., Daunys, D., Bučas, M. and Bacevičius, E., 2012. Mapping an ecosystem 1557 service: A quantitative approach to derive fish feeding ground maps. Oceanologia 54, $1558 \quad 491-505$. 
66

Sissenwine, M., Symes, D., 2007. Reflections on the Common Fisheries Policy. Report to the general directorate for fisheries and maritime affairs of the European commission, pp. 1-75.

1562 Snickars, M., Sandström, A., Lappalainen, A., Mattila, J., Rosqvist, K., Urho, L., 2009.

1563 Fish assemblages in coastal lagoons in land-uplift succession: the relative importance of 1564 local and regional environmental gradients. Estuarine, Coastal and Shelf Science 81, 2471565256.

1566 Snickars, M., Sundblad, G., Sandström, A., Ljunggren, L., Bergström, U., Johansson, G., 1567 Mattila, J., 2010. Habitat selectivity of substrate-spawning fish: modelling requirements 1568 for the Eurasian perch Perca fluviatilis. Marine Ecology Progress Series 398, 235-243.

1569 Snickars, M., Weigel, B., Bonsdorff, E., 2015. Impact of eutrophication and climate 1570 change on fish and zoobenthos in coastal waters of the Baltic Sea. Marine Biology 162, 1571 141-151.

1572 Sparholt, H., 1994. Fish species interactions in the Baltic Sea. Dana 10, 131-162.

1573 Stål, J., Pihl, L., Wennhage, H., 2007. Food utilisation by coastal fish assemblages in 1574 rocky and soft bottoms on the Swedish west coast: Inference for identification of 1575 essential fish habitats. Estuarine, Coastal and Shelf Science 71, 593-607.

1576 Stelzenmüller, V., Lee, J., Garnacho, E., Rogers, S.I., 2010. Assessment of a Bayesian 1577 Belief Network-GIS framework as a practical tool to support marine planning. Marine 1578 Pollution Bulletin 60, 1743-1754.

1579 Støttrup, J.G., Stenberg, C., Dahl, K., Kristensen, L.D., Richardson, K., 2014. Restoration 1580 of a temperate reef: Effects on the fish community. Open Journal of Ecology 4:104515811059. 
Støttrup, J.G., Dinesen, G.E., Janssen, H., Gillgren, C., Schernewski, G., 2016. Re-visiting

1583

1584

1585

1586

1587

1588

1589

1590

1591

1592

1593

1594

1595

1596

1597

1598

1599

1600

1601

1602

1603

1604

1605

1606

ICM theory and practice: Lessons learned from the Baltic Sea Region. Ocean and Coastal Management 139, 64-76.

Sundblad, G., Bergström, U., 2014. Shoreline development and degradation of coastal fish reproduction habitats. Ambio 43, 1020-1028.

Sundblad, G., Bergström, U., Sandström, A., 2011. Ecological coherence of marine protected area networks: a spatial assessment using species distribution models. Journal of Applied Ecology 48, 112-120.

Sundblad, G., Bergström, U., Sandström, A., Eklöv, P., 2014. Nursery habitat availability limits adult stock sizes of predatory coastal fish. ICES Journal of Marine Science 71, 672680.

Thompson, R.C., Crowe, T.P., Hawkins, S.J., 2002. Rocky intertidal communities: past environmental changes, present status and predictions for the next 25 years. Environmental Conservation 29, 168-191.

Thomsen, J., Gutowska, M.A., Saphorster, J., Heinemann, A., Trubenbach, K., Fietzke, J., Hiebenthal, C., Eisenhauer, A., Körtzinger, A., Wahl, M., Melzner, F., 2010. Calcifying invertebrates succeed in a naturally $\mathrm{CO}_{2}$-rich coastal habitat but are threatened by high levels of future acidification. Biogeosciences 7, 3879-3891.

Thrush, S.F., Dayton, P.K., 2010. What can ecology contribute to ecosystem-based management? Annual Review of Marine Science 2, 419-441.

Torn, K., Herkül, K., Martin, G., Oganjan, K. (2017). Assessment of quality of three marine benthic habitat types in northern Baltic Sea. Ecological Indicators, 73, 772-783.

Turner, S.J., Thrush, S.F., Hewitt, J.E., Cummings, V.J., Funnell, G., 1999. Fishing impacts and the degradation or loss of habitat structure. Fisheries Management and Ecology 6, 401-420. 
1607 Ustups, D., Müller-Karulis, B., Bergström, U., Makarchouk, A., Sics, I., 2013. The 1608 influence of environmental conditions on early life stages of flounder (Platichthys flesus) 1609 in the central Baltic Sea. Journal of Sea Research 75, 77-84.

1610 Ustups, D., Bergström, U., Florin, A.-B., Kruze, E., Zilniece, D., Elferts, D., Knospina, E, 1611 Uzars, D. (2016). Diet overlap between juvenile flatfish and the invasive round goby in 1612 the central Baltic Sea. Journal of Sea Research, 107, 121-129.

1613 Uusitalo, L., Kuikka, S., Kauppila, P., Söderkultalahti, P., Bäck, S., 2012. Assessing the 1614 roles of environmental factors in coastal fish production in the northern Baltic Sea: A 1615 Bayesian network application. Integrated Environmental Assessment and Management $16168,445-455$.

1617 Uusitalo, L., Korpinen, S., Andersen, J.H., Niiranen, S., Valanko, S., Heiskanen, A.S., 1618 Dickey-Collas, M., 2016. Exploring methods for predicting multiple pressures on 1619 ecosystem recovery: A case study on marine eutrophication and fisheries. Continental 1620 and Shelf Research 121, 48-60.

1621 Vahteri, P., Vuorinen, I., 2016. Continued decline of the bladderwrack, Fucus 1622 vesiculosus, in the Archipelago Sea, northern Baltic proper. Boreal Environment 1623 Research 21, 373-386.

1624 Vahteri, P., Mäkinen, A., Salovius, S., Vuorinen, I., 2000. Are drifting algal mats 1625 conquering the bottom of the Archipelago Sea, SW Finland? Ambio 29, 338-343.

1626 Vanhatalo, J., Veneranta, L., Hudd, R., 2012. Species distribution modeling with 1627 Gaussian processes: A case study with the youngest stages of sea spawning whitefish 1628 (Coregonus lavaretus L. s.l.) larvae. Ecological Modelling 228, 49-58.

1629 Vasconcelos, R.P., Eggleston, D.B., Le Pape, O., Tulp, I., 2014. Patterns and processes of 1630 habitat-specific demographic variability in exploited marine species. ICES Journal of 1631 Marine Science 71, 638-647. 
Vetemaa, M., Eschbaum, R., Verliin, A., Albert, A., Eero, M., Lillemägi, R., Pihlak, M.,

1633

1634 Estonia.

1635 Ecology of Freshwater Fish 15, 211-220.

1636

1637

1638

1639

1640

1641

1642 affect essential fish habitat? Estuaries 22, 793-802. 1258.

Saat, T., 2006. Annual and seasonal dynamics of fish in the brackish-water Matsalu Bay,

Vogt, H., Schramm, W., 1991. Conspicuous decline of Fucus in Kiel Bay (western Baltic): what are the causes? Marine Ecology Progress Series 69, 189-194.

Wastie, J., 2014. Assessing the importance of freshwater tributary systems for the recruitment of Eurasian perch (Perca fluviatilis) in Baltic Sea coastal ecosystems. MScthesis, Swedish University of Agricultural Sciences, 30 pp.

Weinstein, M.P., Balletto, J.H., 1999. Does the common reed, Phragmites australis,

Wennhage, H., Pihl, L., 2002. Fish feeding guilds in shallow rocky and soft bottom areas on the Swedish west coast. Journal of Fish Biology 61, 207-228.

Węsławski, J.M., Warzocha, J., Wiktor, J., Urbański, J., Bradtke, K., Kryla, L., Tatarek, A., Kotwicki, L., Piwowarczyk, J., 2009. Biological valorisation of the southern Baltic Sea (Polish Exclusive Economic Zone). Oceanologia 51, 415-435.

Węsławski, J.M., Kryla-Straszewska, L., Piwowarczyk, J., Urbański, J., Warzocha, J., Kotwicki, L., Wlodarska-Kowalczuk, M., Wiktor, J., 2013. Habitat modelling limitations Puck Bay, Baltic Sea - a case study. Oceanologia 55, 167-183.

Westin, L., Limburg, K.E., 2002. Newly discovered reproductive isolation reveals sympatric populations of Esox lucius in the Baltic. Journal of Fish Biology 61, 1647-1652. Widdows, J., 1991. Physiological ecology of mussel larvae. Aquaculture 94, 147-163.

Winkler, H.M., 1996. Peculiarities of fish communities in estuaries of the Baltic Sea; the Darss-Zingst-Bodden Chain as an example. Oceanographic Literature Review 12, 
1657 Yáñez-Arancibia, A., Day, J.W., Reyes, E., 2013. Understanding the coastal ecosystem-

1658 based management approach in the Gulf of Mexico. Journal of Coastal Research 63, 2431659261.

1660

1661

1662

1663

1664

1665

1666

1667

1668

1669 Web-links:

1670 http://ec.europa.eu/environment/nature/conservation/species/redlist/index en.htm

1671 (page visited 27/11/2017)

1672 http://helcom.fi/helcom-at-work/projects/holas-ii/(page visited 27/11/2017)

1673 http://helcom.fi/helcom-at-work/projects/tapas (page visited 27/11/2017)

1674 http://www.marlin.ac.uk/ (page visited 27/11/2017)

1675 http://paikkatieto.ymparisto.fi/velmu/ (page visited 27/11/2017)

1676 http://www.helcom.fi// (page visited 27/11/2017)

1677 https://www.nobanis.org/marine-identification-key/fish/fish-start/fish-

1678 key/neogobius-melanostomus/ (page visited 27/11/2017) 


\begin{tabular}{|c|c|c|c|c|}
\hline Direct evidence & & & & \\
\hline Fish species & Area & Studied topic(s) & Central findings & Reference(s) \\
\hline $\begin{array}{l}\text { Perch (Perca fluviatilis) } \\
\text { and pikeperch (Sander } \\
\text { lucioperca) }\end{array}$ & Sweden and Finland & $\begin{array}{l}\text { Species distribution modelling was used on } \\
\text { coastal data from twelve archipelago areas } \\
\text { where the distribution of nursery habitats for } \\
\text { perch and pikeperch was related to the size of } \\
\text { adult populations. }\end{array}$ & $\begin{array}{l}\text { Habitat availability explains almost half of the } \\
\text { variation in population size and indicates a } \\
\text { crucial role in limiting adult stock sizes. }\end{array}$ & Sundblad et al. 2014 \\
\hline $\begin{array}{l}\text { Whitefish (Coregonus } \\
\text { lavaretus) }\end{array}$ & $\begin{array}{l}\text { Gulf of Bothnia, } \\
\text { Sweden and Finland }\end{array}$ & $\begin{array}{l}\text { Species distribution modelling was used on } \\
\text { coastal data on whitefish to evaluate } \\
\text { relationships between variables describing EFH } \\
\text { and larval production. }\end{array}$ & $\begin{array}{l}\text { Metrics describing EFH and their current level } \\
\text { of human impact are the most important ones } \\
\text { for the abundance of whitefish larvae. }\end{array}$ & $\begin{array}{l}\text { Vanhatalo et al. } \\
2012\end{array}$ \\
\hline $\begin{array}{l}\text { Perch, pikeperch, Baltic } \\
\text { herring (Clupea harengus } \\
\text { membras) and sprat } \\
\text { (Osmerus eperlanus) }\end{array}$ & Finnish coast & $\begin{array}{l}\text { Species distribution modelling was used on } \\
\text { larval survey data of a number of fish species to } \\
\text { assess the most important reproduction } \\
\text { habitats. }\end{array}$ & $\begin{array}{l}\text { Identification of highly effective spawning } \\
\text { areas, i.e. that production of fish stocks can be } \\
\text { concentrated to very limited areas compared to } \\
\text { the total suitable production areas that are } \\
\text { available. }\end{array}$ & Kallasvuo et al. 2017 \\
\hline Cod (Gadus morhua)* & Baltic Proper & $\begin{array}{l}\text { Various statistical models were used for the } \\
\text { determination of relationships between the } \\
\text { volume of EFH (coastal and non-coastal) } \\
\text { available for Baltic cod and processes affecting } \\
\text { adult stock size. }\end{array}$ & $\begin{array}{l}\text { Positive relationships exist between the volume } \\
\text { of EFH and cod reproduction (and thus the } \\
\text { adult stock size) as well as between habitat } \\
\text { availability for juvenile cod (nursery areas) and } \\
\text { density-dependent growth. }\end{array}$ & $\begin{array}{l}\text { MacKenzie et al. } \\
2000, \text { Cardinale and } \\
\text { Arrhenius 2000, } \\
\text { Hinrichsen et al. } \\
2017\end{array}$ \\
\hline $\begin{array}{l}\text { Flounder (Platichtys } \\
\text { flesus)* }\end{array}$ & Baltic Proper & $\begin{array}{l}\text { Spawning area availability of pelagic spawning } \\
\text { flounder through time was quantified by } \\
\text { species distribution modelling, and related to } \\
\text { larval production and adult stock sizes. }\end{array}$ & $\begin{array}{l}\text { Decreases in spawning habitat availability have } \\
\text { been accompanied by a decrease in larval } \\
\text { production as well as a decrease in adult stock } \\
\text { sizes. }\end{array}$ & $\begin{array}{l}\text { Ustups et al. } 2013 \text {, } \\
\text { Orio et al. } 2017\end{array}$ \\
\hline Indirect evidence & & & & \\
\hline Fish species & Area & Studied topic(s) & Central findings & Reference(s) \\
\hline Perch & Sweden and Finland & $\begin{array}{l}\text { Investigation of how coastal spawning habitats } \\
\text { for perch are dependent on the type of } \\
\text { substrate. }\end{array}$ & $\begin{array}{l}\text { Vegetated substrates providing rigidity and } \\
\text { structural complexity are preferred by the } \\
\text { perch. Also, shallow depths and sheltered areas } \\
\text { are preferred characteristics. }\end{array}$ & Snickars et al. 2010 \\
\hline Juvenile fish & Sweden and Finland & $\begin{array}{l}\text { Relationships between fish reproduction data } \\
\text { and the quality (species composition) of } \\
\text { macrophyte communities on shallow soft } \\
\text { bottoms were investigated }\end{array}$ & $\begin{array}{l}\text { Investigated bays that are dominated by stress } \\
\text { sensitive macrophyte species are important } \\
\text { nursery areas for fish. }\end{array}$ & $\begin{array}{l}\text { Hansen and } \\
\text { Snickars } 2014\end{array}$ \\
\hline Pike (Esox lucius) & Southern Finland & $\begin{array}{l}\text { Habitat choice and survival of pike in } \\
\text { filamentous algae and in bladder-wrack were }\end{array}$ & $\begin{array}{l}\text { In the presence of predators, pike larvae prefer } \\
\text { and also survive better in filamentous algae }\end{array}$ & $\begin{array}{l}\text { Engström-Öst et al. } \\
2007\end{array}$ \\
\hline
\end{tabular}




\begin{tabular}{|c|c|c|c|c|}
\hline & & tested experimentally. & than in bladderwrack. & \\
\hline Pike & Southern Finland & $\begin{array}{l}\text { The performance of larval pike under the } \\
\text { influence of turbidity induced by phytoplankton } \\
\text { was investigated experimentally. }\end{array}$ & $\begin{array}{l}\text { Larval weight of pike is lower in turbid water, } \\
\text { despite that pike larvae here spend less time in } \\
\text { vegetation and attack more prey. }\end{array}$ & $\begin{array}{l}\text { Engström-Öst and } \\
\text { Mattila } 2008\end{array}$ \\
\hline Commercial fish species & $\begin{array}{l}\text { Entire Finnish } \\
\text { coastline }\end{array}$ & $\begin{array}{l}\text { Relationships between many environmental } \\
\text { variables (N, P, chlorophyll } a \text {, duration of ice } \\
\text { coverage in winter, shore density in the area } \\
\text { and salinity) and the CPUE (of reported } \\
\text { commercial catches) were investigated. }\end{array}$ & $\begin{array}{l}\text { Shore density, corresponding closely to the } \\
\text { availability of EFH, is an important factor for all } \\
\text { species, although the strongest effects occur for } \\
\text { pike. }\end{array}$ & Uusitalo et al. 2012 \\
\hline Flounder & Southern Finland & $\begin{array}{l}\text { Fishery-independent data on adult flounder as } \\
\text { well as historical and present-state data on } \\
\text { juveniles in shallow coastal areas were utilized } \\
\text { to study relationships between EFH and the } \\
\text { production of flounder. }\end{array}$ & $\begin{array}{l}\text { Increased coverage of filamentous algae } \\
\text { correlates with a pronounced decrease in the } \\
\text { abundance of juvenile flounder. A simultaneous } \\
\text { decrease in the abundance of adult flounders } \\
\text { indicates that the declined EFH availability for } \\
\text { juveniles acts as a bottleneck for the population. }\end{array}$ & $\begin{array}{l}\text { Jokinen et al. 2015, } \\
2016\end{array}$ \\
\hline Pikeperch & Germany & $\begin{array}{l}\text { Investigation of pikeperch spawning in inner } \\
\text { coastal waters of salinities around 5-6. }\end{array}$ & $\begin{array}{l}\text { Coastal EFH of lower salinities are the base } \\
\text { for nearly } 40 \% \text { of the total annual catch of } \\
\text { pikeperch in waters with higher salinities } \\
\text { (around 10). }\end{array}$ & $\begin{array}{l}\text { Winkler 1996, } \\
\text { Winkler et al. } \\
\text { unpubl. }\end{array}$ \\
\hline Pike & $\begin{array}{l}\text { Southeastern } \\
\text { Sweden }\end{array}$ & $\begin{array}{l}\text { The recruitment of pike was studied in coastal } \\
\text { wetlands restored in different ways. }\end{array}$ & $\begin{array}{l}\text { In restored wetlands with temporally flooded } \\
\text { terrestrial vegetation, juvenile pike migration } \\
\text { increase from a few thousand individuals in } \\
\text { previous years to }>100,000 \text { individuals } \\
\text { afterwards. }\end{array}$ & Nilsson et al. 2014 \\
\hline Pike & Swedish east coast & $\begin{array}{l}\text { The relative importance of fresh and brackish } \\
\text { water recruitment areas (spawning habitat } \\
\text { preferences) for pike was examined through } \\
\text { the use of otolith Sr:Ca profiles. }\end{array}$ & $\begin{array}{l}\text { For pike, } 20 \% \text { hatches in brackish water in the } \\
\text { Forsmark area at the } 60^{\circ} \mathrm{N} \text { latitude and } 80 \% \\
\text { hatches in brackish water in the Kalmar Sound } \\
\text { at the } 56^{\circ} \mathrm{N} \text { latitude. }\end{array}$ & Engstedt et al. 2010 \\
\hline $\begin{array}{l}\text { Pike, whitefish, burbot } \\
\text { (Lota lota) and ide } \\
\text { (Leuciscus idus) }\end{array}$ & Estonia & $\begin{array}{l}\text { The relative importance of fresh and brackish } \\
\text { water recruitment areas (spawning habitat } \\
\text { preferences) was examined for brackish water } \\
\text { fish populations through the use of otolith Sr:Ca } \\
\text { profiles. }\end{array}$ & $\begin{array}{l}\text { The relative importance of coastal wetlands and } \\
\text { river-mouths as spawning grounds compared to } \\
\text { brackish water areas is demonstrated. There } \\
\text { are indications that brackish water spawning is } \\
\text { becoming rarer. }\end{array}$ & $\begin{array}{l}\text { Rohtla et al. 2012, } \\
\text { 2014, 2015, 2017, } \\
\text { Rohtla 2015 }\end{array}$ \\
\hline
\end{tabular}

Table 1. Direct and indirect evidence from the Baltic Sea with regard to the effects of EFH on fish population size. *Note that the results for cod and flounder in the Baltic Proper are not strictly coastal (see text for more details). 